\title{
Artificial Photosynthesis: Where are we now? Where can we go?
}

Ralph L. House ${ }^{\mathrm{a}}$, Neyde Yukie Murakami Iha ${ }^{\mathrm{b}}$, Rodolfo L. Coppo ${ }^{\mathrm{b}}$, Leila Alibabaei ${ }^{\mathrm{a}}$, Benjamin D. Sherman ${ }^{\mathrm{a}}$, Peng Kang ${ }^{\mathrm{a}}$, M. Kyle Brennaman ${ }^{\mathrm{a}}$, Paul G. Hoertz ${ }^{\mathrm{a}}$, and Thomas J. Meyer ${ }^{\mathrm{a} *}$.

${ }^{a}$ Department of Chemistry CB\#3290, University of North Carolina at Chapel Hill, Chapel Hill, NC 27599

${ }^{\mathrm{b}}$ Laboratory of Photochemistry and Energy Conversion, Instituto de Química, Universidade de Sao Paulo - USP, Av. Prof. Lineu Prestes, 748, 05508-900, Sao Paulo, SP, Brazil

* To whom correspondence should be addressed: tjmeyer@unc.edu

\section{Abstract:}

Widespread implementation of renewable energy technologies, while preventing significant increases in greenhouse gas emissions, appears to be the only viable solution to meeting the world's energy demands for a sustainable energy future. The final energy mix will include conservation and energy efficiency, wind, geothermal, biomass, and others, but none more ubiquitous or abundant than the sun. Over several decades of development, the cost of photovoltaic cells has decreased significantly with lifetimes that exceed 25 years and there is promise for widespread implementation in the future. However, the solar input is intermittent and, to be practical at a truly large scale, will require an equally large capability for energy storage. One approach involves artificial photosynthesis and the use of the sun to drive solar fuel reactions for water splitting into hydrogen and oxygen or to reduce $\mathrm{CO}_{2}$ to reduced carbon fuels. An early breakthrough in this area came from an initial report by Honda and Fujishima on photoelectrochemical water splitting at $\mathrm{TiO}_{2}$ with UV excitation. Significant progress has been made since in exploiting semiconductor devices in water splitting with impressive gains in spectral coverage and solar efficiencies. An alternate, hybrid approach, which integrates molecular light absorption and catalysis with the band gap properties of oxide semiconductors, the dye-sensitized photoelectrosynthesis cell (DSPEC), has been pioneered by the University of North Carolina Energy Frontier Research Center (UNC EFRC) on Solar Fuels. By utilizing chromophore-catalyst assemblies, core/shell oxide structures, and surface stabilization, the EFRC recently demonstrated a viable DSPEC for solar water splitting.

\section{Keywords:}

Artificial Photosynthesis; Solar Fuels; Photoelectrochemical; Dye-Sensitized; Water Oxidation; Carbon Dioxide Reduction

\section{Introduction:}

Energy is a unifying theme across the physical and natural sciences, geopolitics, and economics. How we use, distribute and manage our energy resources is at the forefront of the global agenda. There is steadily increasing demand as global affluence increases, and the nagging deleterious effects of climate change if renewable resources aren't used to supply this increasing demand. As a perspective of present and future needs, in September 2000 the United Nations millennium development goals (MDGs) promised to halve the global population living in extreme poverty by 2015 . The result has been remarkably successful, decreasing the number 
of people subsisting on $\$ 1$ a day from $43 \%$ in 1990 to $21 \%$ by $2010 .{ }^{1}$ In the summer of 2013 , a list of post-2015 MDGs were recommended to the UN, most notably the eradication of extreme poverty by 2030. As shown in many studies, an increase in the global standard of living will result in increasing energy consumption. In Sub-Saharan Africa alone the economy is estimated to quadruple by 2040 with an $80 \%$ increase in energy demand. ${ }^{2}$

Until now, the global community's energy demands have been largely met by fossil fuels. On the short term, the concept of "Peak Oil" and the predicted decline of oil reserves has been overcome by the advent of modern exploration techniques and the use of horizontal drilling and hydraulic fracturing technologies allowing access to oil and shale gas reserves that were previously out-of-reach. Use of the new technologies comes with an environmental risk, including the impact of methane leakage on global warming ${ }^{3}$ and potential contamination of ground-water. In addition, many of the predictions for shale gas reserves relied on coarse-grain modeling $^{4}$ with more recent fine-grain analyses resulting in more conservative forecasts. They predict a peak in production in 2020 followed by slow declines thereafter. ${ }^{4,5}$

In any case, the combustion of fossil fuels has been implicated in the increasing levels of atmospheric $\mathrm{CO}_{2}$ and the resulting detrimental effects on the global climate. At the time of this writing, delegates from 196 countries are meeting at the $20^{\text {th }}$ Conference of the Parties to the UN Framework Convention on Climate Change to detail objectives that will insure that the rise in global temperature will not rise more than $2^{\circ} \mathrm{C}$ by developing policies that reduce greenhouse gas emissions. ${ }^{6}$ Computer models show that further increases could result in catastrophic damage to the planet with drought, melting ice sheets, and shrinking glaciers leading to rising sea levels and food and water shortages. ${ }^{6}$ The cause for alarm is as much economic as environmental. An increase of $\sim 20$ inches in sea level would result in the displacement of an estimated 150 million people from submerged port cities by 2070 (including areas of Shanghai and New York City), with property losses of $\$ 35$ trillion. $^{7}$

To prevent a temperature rise beyond $2^{\circ} \mathrm{C}$ global emissions must be controlled peaking within the next ten years and declining to half of the current level by 2050. The international community is responding, with the US pledging to reduce 2005 level emissions by $28 \%$ by 2025 , the EU planning to cut their emissions by $40 \%$ of 1990 levels by 2030, and China reaching peak emissions by $2030 .^{8}$

Continued reliance on fossil fuels will soon present a global paradox with eradication of poverty and decreasing global emissions in direct competition. If the increasing demand for energy is met with traditional fossil fuels without $\mathrm{CO}_{2}$ capture and storage, reduced emission goals will fail. To achieve both, new technologies are needed to meet the energy demands of developing economies without increasing the global rate of greenhouse gas emissions.

The need will be met by integrating a variety of energy sources - wind, biomass, geothermal, hydro, etc. - but the major renewable, carbon free energy source is the sun. In one hour the sun provides $\sim 10,000$ times the energy currently consumed by the world in a year. In the past five years the cost of providing electricity, using either solar or wind power, has plummeted making these renewable options less expensive than coal or natural gas in some markets including the Great Plains and Southwestern United States. ${ }^{9}$ These advances have been triggered by new technology and have been fueled, in part, by generous tax subsidies that have decreased the cost of utility-scale solar electricity to 5.6 cents $/ \mathrm{kW}$-h and wind to 1.4 cents $/ \mathrm{kW}-\mathrm{h}$. By comparison, the cost for natural gas is currently 6.1 cents $/ \mathrm{kW}$-h and for coal is 6.6 cents $/ \mathrm{kW}$ h. Without subsidies, the cost of solar would rise to 7.2 cents $/ \mathrm{kW}$-h and wind to 3.7 cents $/ \mathrm{kW}-\mathrm{h}$. 


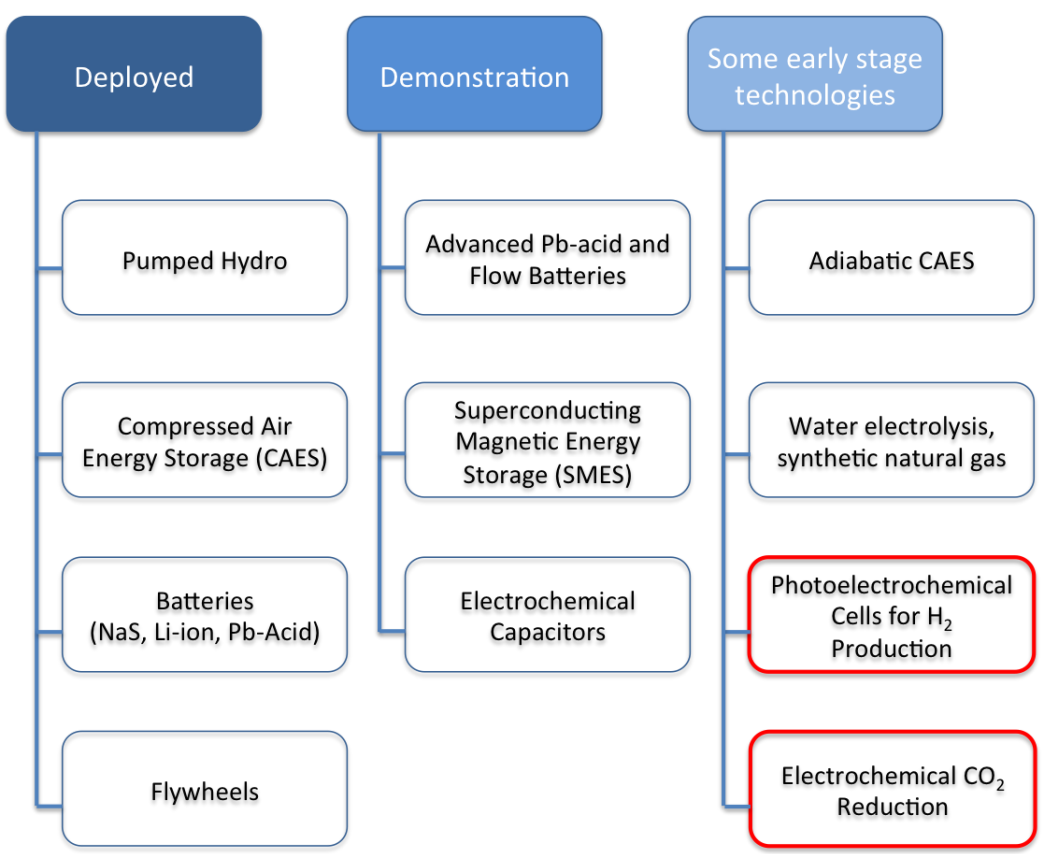

Figure 1. Examples of energy storage technologies and their relative stages of development. Technologies based on artificial photosynthesis are highlighted in red. Adapted from Department of Energy "Grid Energy Storage" 10

More importantly, the real cost of photovoltaic cells (PV) decreased by a factor 59 between 1976 and 2008 with device lifetimes that now exceed 25 years. ${ }^{11}$

Although promising and growing in importance in the global energy economy, both solar and wind energy suffer from a serious limitation. Both are intermittent. To replace conventional power plants, methods for storing the output of both will need to be developed, for use at night for solar and when the wind isn't blowing. Driven by the need for load leveling and, increasingly to support wind and solar, the field of energy storage is rapidly growing. It includes a diverse range of technologies based on chemical or mechanical storage methods. Examples of chemical storage include batteries and thermal energy storage in materials with high thermal capacitance. Compressed air, flywheels, and pumped hydro, are examples of mechanical energy storage. Figure 1 summarizes other energy storage examples and their current stages of development. In a Grid Energy Storage Report published at the end of 2013, the United States Department of Energy reported that 202 storage systems had been deployed with a cumulative operational capability of $24.6 \mathrm{GW} .{ }^{10}$ The vast majority of this stored power ( 95\%) was sourced from pumped hydro plants operated by major utility companies (Figure 2). Despite its large presence as a source for energy storage, it is unlikely that pumped hydro will become a predominant energy storage medium. In addition to being limited to areas proximal to a large body of water, the energy density as a function of weight is comparatively low (Figure 3). In a recent report, Energy Storage Update reported that the number of existing and planned energy storage projects in the US is dominated by Li-ion batteries $(\sim 32 \%)$. This is followed by thermal storage $(\sim 20 \%)$ and pumped hydro $(\sim 9 \%){ }^{12}$ 


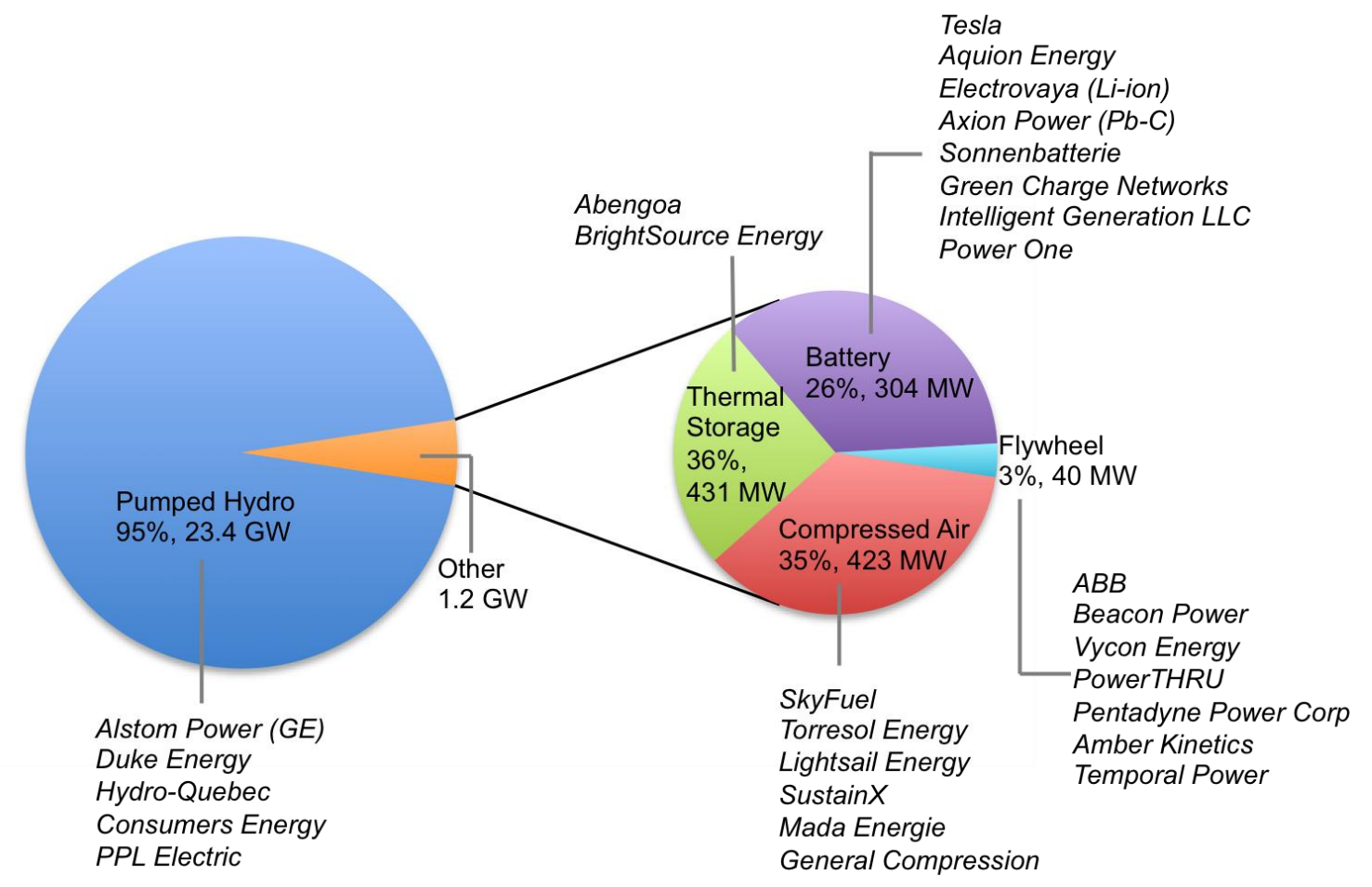

Figure 2. Energy storage technologies currently in use based on market share in the United States at the end of 2013. Examples of companies involved in each sector are shown. Adapted from Department of Energy "Grid Energy Storage"10

A number of companies, both established and early-stage ventures, with examples shown in Figure 2, have begun to develop alternatives. In all of these schemes, the energy density of the storage medium pales in comparison to the energy density in chemical bonds (Figure 3). Hydrogen gas is the most energy dense and the advantages of switching to a hydrogen-based economy are many. The cost of storing energy as hydrogen is cheaper than storing it as electricity. ${ }^{11}$ However, the infrastructure for dealing with this gaseous fuel is still nascent because of the considerable infrastructure required to support a hydrogen economy. Carbonbased fuels are relatively inexpensive with a pre-existing infrastructure in place for storage and energy extraction. However, to use them in solar energy conversion and storage schemes will require the evolution of new technologies that mimic plants by integrating light absorption, energy conversion, and catalysis of chemical reactions by artificial photosynthesis.

Photosynthesis in green plants evolved billions of years ago and is extraordinarily complex. It consists of 5 membrane-compartmentalized functional units in the thylakoid membrane of the chloroplast with the external rubisco enzyme for $\mathrm{CO}_{2}$ reduction. It is a remarkable feat of biological engineering but, given its complexity, it is an inspiration for artificial photosynthesis, not a model.

\section{A Brief Review of Photoelectrochemical Cells and Artificial Photosynthesis:}

The initial publication by Honda and Fujishima on light-driven water splitting by direct bandgap excitation of $\mathrm{TiO}_{2}{ }^{13,14}$ led to a new area of research. Since their initial study, many publications have appeared on photoelectrochemical water splitting and solar fuels production 
based on semiconductors in a variety of liquid junction cell configurations and designs. A summary of water splitting cells is shown in Table 1 based on the criteria developed by Lewis et al. ${ }^{15}$ and of Newman et al. ${ }^{11}$ It has been updated based on an extensive literature survey. Except for a few recent examples, with cell configurations worth noting, the entries selected are for devices with solar hydrogen efficiencies of $>2 \%$.

Solar-to-hydrogen conversion efficiencies in semiconductor photoelectrochemical cells (PEC) improved in performance from less than $1 \%$ to $12 \%$ from 1975 to $1980 .{ }^{16}$ In 1982 , Aharon-Shalom and Heller ${ }^{17}$ reported efficiencies of 11.4 and $13.3 \%$ in cells based on single ptype $\mathrm{p}$-InP photocathodes, coated with either rhenium or rhodium, respectively. Periodic cycling of the photocathodes to the open circuit potential, $\mathrm{V}_{\mathrm{OC}}$, was required to maintain cell efficiencies by restoring passivating oxide layers to minimize recombination.

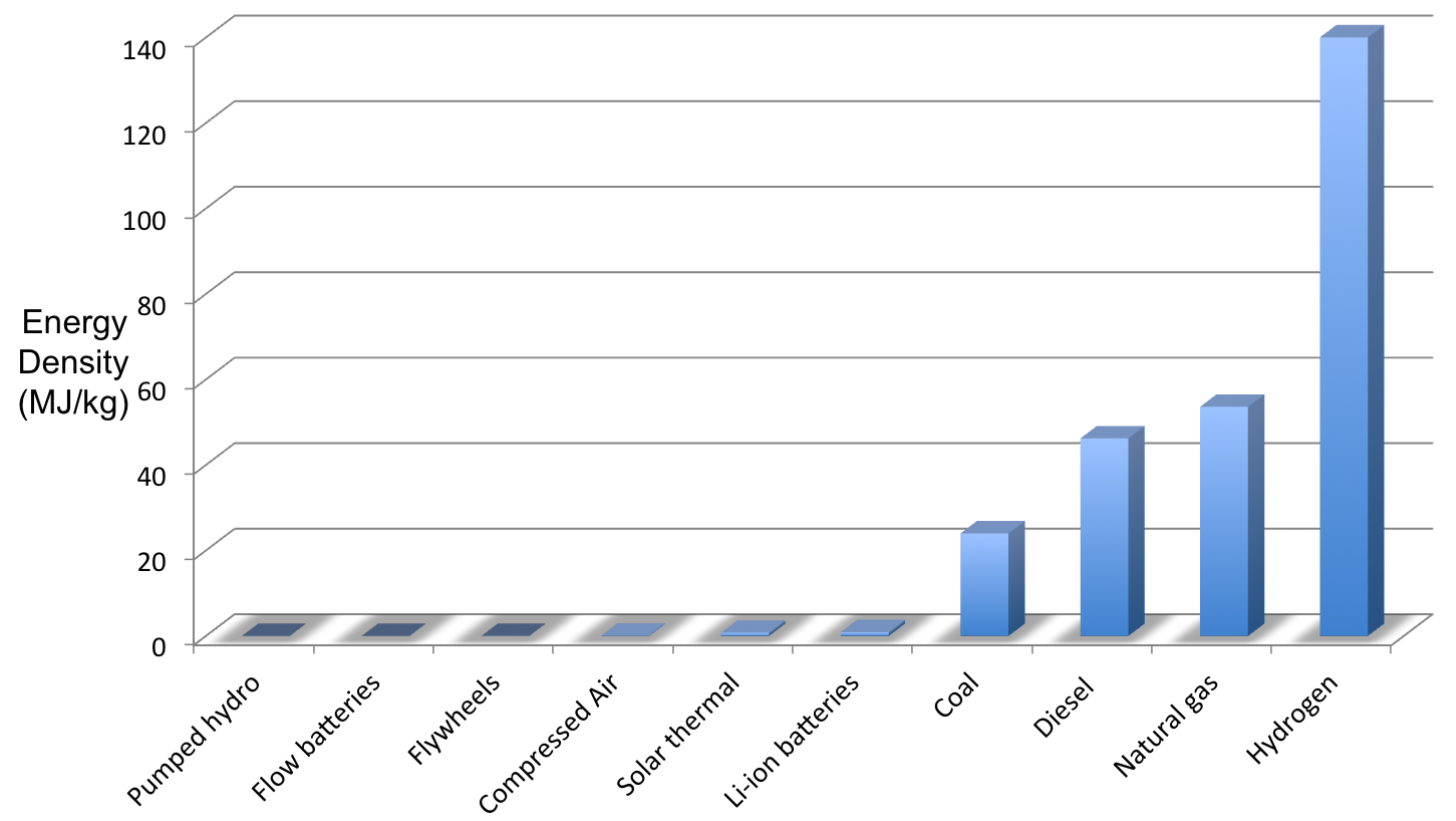

Figure 3. Energy storage media plotted as a function of energy density.

In 1987, Bockris et al. ${ }^{18}$ described a tandem photocathode (p-InP with electrodeposited $\mathrm{Pt}$ )/photoanode ( $\mathrm{n}$-GaAs protected by Mn-oxide) PEC with an efficiency of $8.2 \%$ for solar hydrogen conversion with a 10-hour-stability window which decreased in efficiency by $10 \%$ after the first hour of operation.

A hydrogen production efficiency of $12.4 \%$ was reported for an integrated, monolithic PEC/ $\mathrm{PV}$ device, with a $\mathrm{p}-\mathrm{GaInP}_{2}$ working photocathode and $\mathrm{p} / \mathrm{n}-\mathrm{GaAs}$ anode by Khaselev and Turner ${ }^{19}$ in 1998. In 2001, they improved the efficiency to $16.5 \%$ in a multi-junction, monolithic PV/electrolysis cell with a tandem $\mathrm{n} / \mathrm{pn} / \mathrm{p}$ GaInP/GaAs junction in ohmic contact with the external solution. ${ }^{20}$

A remarkable conversion efficiency of $18.3 \%$ was obtained by Licht et al. in $2000^{21}$ for a device based on p/n-AlGaAs on Si for evolving $\mathrm{H}_{2}$ and $\mathrm{O}_{2}$ with $\mathrm{RuO}_{2}$ and $\mathrm{Pt}$ (black) as catalysts. The resulting solar photoelectrolysis cell maintained a steady state photocurrent for over $14 \mathrm{~h}$.

Devices based on triple-junction amorphous silicon or III-V semiconductors have demonstrated fair efficiencies, see Table 1, but with noteworthy stabilities with continuing 
performance for up to 31 days achieved by Kelly and Gibson. ${ }^{22}$ Cost and the complexity of device preparation are major barriers to commercial application. ${ }^{23}$

Simpler approaches with Tandem cells for water cleavage based on an oxide photoanode and a dye-sensitized solar cell (DSC), with complementary absorbing layers, first appeared in $1999 .^{24}$ In one approach, a structured $\mathrm{WO}_{3}$ photoanode ${ }^{25}$ was used in series with a DSC ${ }^{26,27}$ or an $\mathrm{Fe}_{2} \mathrm{O}_{3}$ photoanode ${ }^{28}$ coupled to a DSC. ${ }^{25}$ In 2012, results for unassisted water splitting were published for $\mathrm{Fe}_{2} \mathrm{O}_{3} / \mathrm{DSC}$ and $\mathrm{WO}_{3} / \mathrm{DSC}$ cells, with $1.17 \%$ and $3.1 \%$ efficiencies, respectively. ${ }^{23}$ The use of a trilayer Tandem device, $\mathrm{Fe}_{2} \mathrm{O}_{3} / \mathrm{DSC}$-squarene dye/DSC-panchromatic dye, achieved an overall conversion efficiency of $1.36 \%$ with a AM1.5 solar light source. ${ }^{29}$

UNC EFRC DSPEC Design

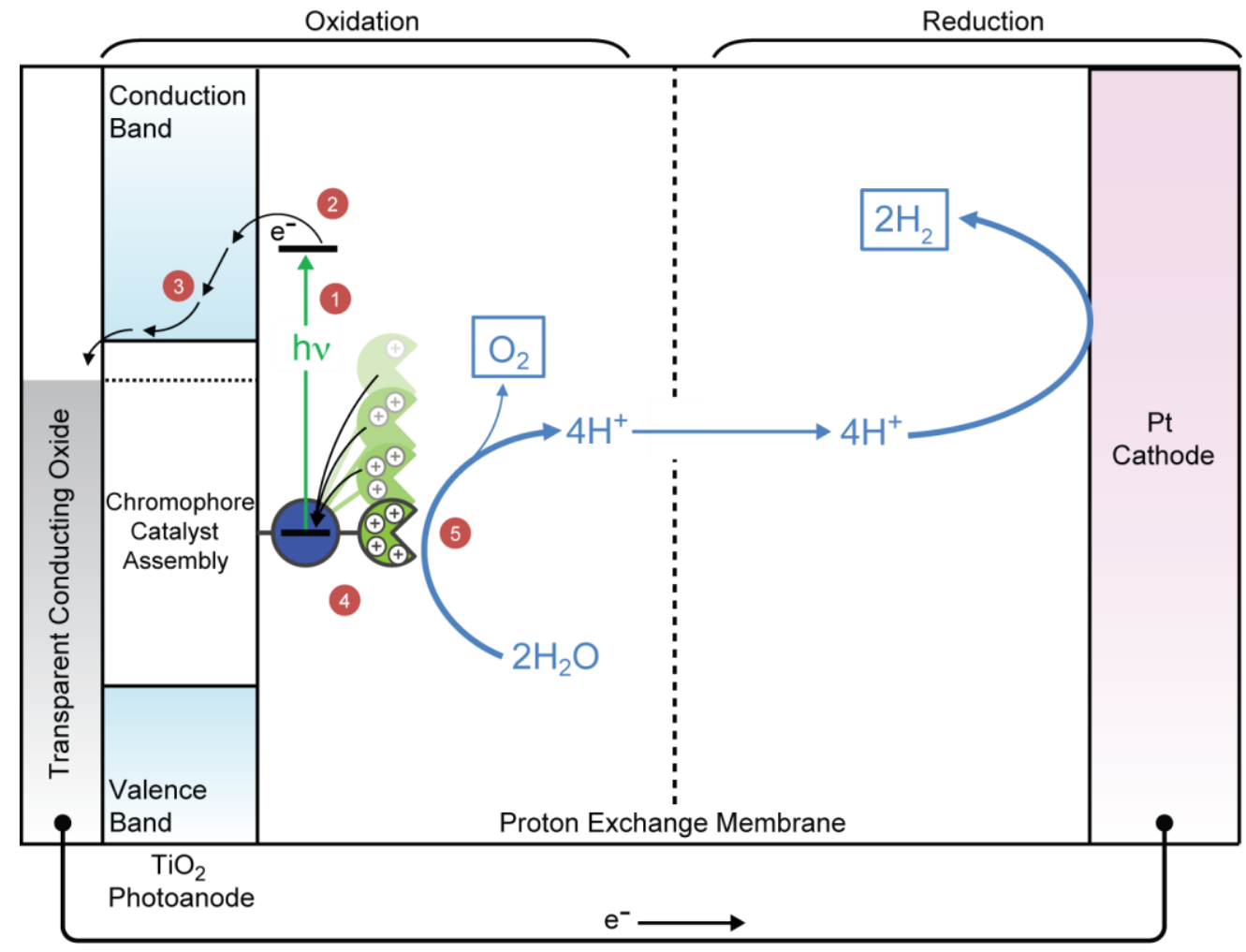

Figure 4. Schematic illustration of a DSPEC for water splitting into hydrogen and oxygen. The steps labeled in the diagram illustrate: (1) Chromophore light absorption to give a surface-bound excited state; (2) Electron injection by the excited state into the conduction band of the semiconductor; (3) Transfer of the injected electron into an external circuit to the cathode. (4) Electron transfer from the catalyst to the chromophore beginning the process of catalyst activation. (5) Steps 1-4 are repeated four times to build up the oxidative equivalents for water oxidation and oxygen evolution at the photoanode. An applied bias of $\sim 0.2 \mathrm{~V}$ is required to drive $\mathrm{H}_{2} \mathrm{O} / \mathrm{H}^{+}$reduction at the cathode to completion.

The development of a related cell based on a perovskite solar cell resulted in a significant increase in solar-to-electric power conversion efficiency with $12.3 \%$ reported for a state of the art $\mathrm{CH}_{3} \mathrm{NH}_{3} \mathrm{PbI}_{3}$ perovskite tandem solar cell with $\mathrm{Ni} \mathrm{Fe} \mathrm{LDH} / \mathrm{Ni}$ foam electrodes for water splitting. Cell lifetime was limited by the stability of the perovskite electrode with improvements possible by passivation. ${ }^{30}$

Attempts to use less expensive, earth-abundant materials have been reported and significant progress has been made. ${ }^{31,32}$ In 2011 , Reece et al. ${ }^{33}$ described a fully integrated solar-driven 
water-splitting device consisting of a triple junction amorphous silicon photovoltaic cell interfaced to a nanoparticle cobalt oxide anode and NiMoZn cathode. Water splitting was carried out with efficiencies of $4.7 \%$ for a wired configuration and $2.5 \%$ for a wireless configuration. Further development led to a PV-EC (photovoltaic driven electrochemical cell) device with an efficiency of $10 \%$ or higher by using multiple single-junction solar cells connected in series as mini-modules with operating stabilities of over 7 days. ${ }^{34}$

An interesting approach utilizing modular non-planar semiconductor geometries and advanced photon management strategies and concepts has been described by the Joint Center for Artificial Photosynthesis (JCAP). A complete water splitting system was assembled from three distinct components - photoanode, bipolar membrane, ${ }^{35}$ and photocathode. With the focus on producing a practical system, JCAP has reported several significant devices, however, all with low conversion efficiencies to date. ${ }^{36,37}$ Various coating strategies have been explored to improve stabilization of semiconductors, including $\mathrm{TiO}_{2}$ coatings grown by atomic layer deposition (ALD) to prevent corrosion ${ }^{38-41}$ and produce durable devices.

Recent reviews have appeared which cover related aspects in artificial photosynthesis including an evaluation of the challenges in generating solar fuels, ${ }^{42-45}$ and on $\mathrm{CO}_{2}$ reduction. ${ }^{46,47}$

\section{The Dye-Sensitized Photoelectrosynthesis Cell (DSPEC):}

The dye-sensitized photoelectrosynthesis cell (DSPEC) is based on molecular level light absorption and excited state electron transfer integrated into the architecture of a dye-sensitized solar cell. Ultimately, the DSPEC offers reasonable costs and simple architectures and materials, but in its development it is still in its infancy. To date, far lower performance metrics have been achieved compared to semiconductor-solution junction-based solar cells. DSPECs combine the electron transport properties of nanocrystalline semiconductor films of $\mathrm{TiO}_{2}$ or $\mathrm{SnO}_{2}{ }^{48-50}$ and transparent nanocrystalline conducting oxide films, such as nanoITO, ${ }^{51,52}$ on transparent conductive oxide substrates. Molecular level-reactions with chromophore-catalyst assemblies, often $\mathrm{Ru}(\mathrm{II})$ polypyridyl based, ${ }^{53}$ are used to produce oxygen at a photoanode ${ }^{51}$ with the assembly attached to the semiconductor oxide surface. ${ }^{54,55}$

\subsection{The University of North Carolina at Chapel Hill Energy Frontier Research Center: Center for Solar Fuels (UNC EFRC):}

Solar energy conversion and storage by artificial photosynthesis is the central theme of the UNC EFRC. Established in 2009 and funded by the Department of Energy: Basic Energy Sciences, the UNC EFRC is directed by Dr. Thomas Meyer and includes 17 faculty members including three members of the National Academy of Sciences. Faculty are largely from UNC, but also from Georgia Institute of Technology, the University of Florida, and the University of Colorado Boulder. The UNC EFRC has been a leader in helping to train the next generation of energy scientists with 70 Postdoctoral Fellows, 100 graduate students, and 30 undergraduate students either trained or in training.

Inspired by natural photosynthesis, the UNC EFRC's goal is to develop the concept of the DSPEC for applications in water splitting and reduction of $\mathrm{CO}_{2}$ to reduced carbon fuels. The DSPEC functions as an artificial leaf utilizing molecular assemblies that both absorb light and catalyze water oxidation at an anode or proton $/ \mathrm{CO}_{2}$ reduction at a cathode. A schematic illustration of a DSPEC for solar water splitting is shown in Figure 4. Given the multidisciplinary 
research demands that arise in achieving a working DSPEC, research in the UNC EFRC uses a modular approach. Separate but integrated teams focus on the development of individual research elements - catalysts, assemblies, dynamics, photoanode, photocathode - before integrating them into prototype devices. After four years of research, this approach has led to the development of a first DSPEC prototype for solar hydrogen production.

\section{DSPEC Research in the UNCEFRC:}

Key elements for solar water splitting with a DSPEC photoanode are illustrated in Figure 5. They include: 1) a nanostructured mesoporous n-type semiconductor oxide electrode that is transparent in the visible region of the spectrum, 2) a light harvesting chromophore, and 3) a water oxidation catalyst (Figure 4). The chromophore and catalyst can be chemically linked or

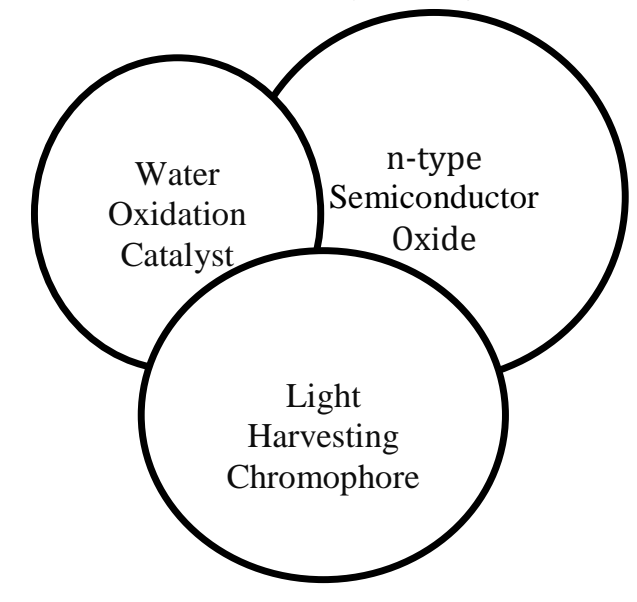

Figure 5. Schematic depiction of key elements in a DSPEC photoanode. surface assembled on nanocrystalline, nanoparticle films of the semiconductor oxide. Phosphonic or carboxylic acid derivatized ligands on the chromophore are used to tether the assembly to the surface of the oxide. In order to control local interfacial dynamics, and minimize back electron transfer following injection, core/shell oxide structures are used. They consist of a thin ( 3-4 nm) external shell of $\mathrm{TiO}_{2}$ deposited on a nanoparticle film core of either a transparent conducting oxide such as indium tin oxide (ITO) or antimony tin oxide (ATO), or on a semiconducting oxide such as $\mathrm{SnO}_{2}$.

In water oxidation at a DSPEC photoanode, four excitation-electron transfer cycles are required to meet the $4 \mathrm{e}^{-} / 4 \mathrm{H}^{+}$demands of the reaction, $2 \mathrm{H}_{2} \mathrm{O}-4 \mathrm{e}^{-}-4$ $\mathrm{H}^{+} \rightarrow \mathrm{O}_{2}$. As illustrated in Figure 4, each activation cycle involves: 1) light absorption, 2) electron injection into the semiconductor, 3) intra-assembly electron transfer activation of the catalyst, and, after four cycles, 4) $\mathrm{O}_{2}$ evolution. In order to maximize photocurrent efficiencies, an applied bias of $\sim 0.2 \mathrm{~V}$ is required when using a $\mathrm{TiO}_{2}$ based photoanode to drive water splitting.

The efficiency of a water splitting DSPEC is determined by the dynamics of the interfacial processes that occur at the photoanode. Transient absorption measurements show that, if favored energetically and with electronic coupling to the surface, injection occurs on the sub-psec timescale. In assemblies that have been investigated by transient absorption measurements, subsequent electron transfer oxidation of the catalyst is also rapid, typically occurring on the subnsec timescale. Following injection, a competition exists between electron migration through the oxide film to the transparent conducting oxide (TCO) and back electron transfer to the oxidized catalyst, surface-bound in the assembly. Even with successful $1 \mathrm{e}^{-}$activation of the catalyst, four excitation-electron transfer activation cycles are required for water oxidation. The accumulated oxidative equivalents have to be long-lived, free from back electron transfer, since the rate of solar insolation in ambient sunlight is only $1-2 \mathrm{~s}^{-1}$. 
Table 1 . Solar-to-fuel efficiencies records.

\begin{tabular}{|c|c|c|c|c|c|c|c|}
\hline Research Group & Year & $\begin{array}{l}\text { Device } \\
\text { Architecture }\end{array}$ & Surface Catalysts & $\begin{array}{l}\text { Materials } \\
\text { Systems }\end{array}$ & Efficiency / \% & Lifetime Testing & Ref \\
\hline Heller et al. & 1982 & Photocathode & Ru, Re, or Rh @ cathode & $\mathrm{p}-\mathrm{InP}$ & $11.4-13.3$ & $\begin{array}{l}\text { Requires periodic cycling to } \\
\mathrm{V}_{\text {oc to maintain high }} \\
\text { efficiency }\end{array}$ & 17 \\
\hline Bockris et al. & 1985 & Tandem PV-PEC & $\begin{array}{l}\mathrm{Pt} @ \text { cathode } \\
\mathrm{RuO}_{2} @ \text { anode }\end{array}$ & Double junction $\mathrm{Si}$ & 2.6 & Not reported & 56 \\
\hline $\begin{array}{l}\text { Kainthla, Zelenay and } \\
\text { Bockris }\end{array}$ & 1987 & Tandem $\mathrm{p} / \mathrm{n}$-PEC & $\begin{array}{l}\mathrm{Pt} @ \text { cathode } \\
\mathrm{MnO} / \mathrm{Pt} @ \text { anode }\end{array}$ & p-InP / n-GaAs & 8.2 & $\begin{array}{l}10 \% \text { efficiency decrease } \\
\text { during first hour, then } \\
\text { remains constant for } 10 \mathrm{~h}\end{array}$ & 18 \\
\hline Tsubomura et al. & 1988 & PV-PEC & $\begin{array}{l}\mathrm{Pt} @ \text { cathode } \\
\mathrm{RuO}_{2} @ \text { anode }\end{array}$ & Double junction $\mathrm{Si}$ & $\begin{array}{l}2.93 \quad(\mathrm{Si} \text { in } \\
\text { solution }) \\
\begin{array}{l}3.23(\mathrm{Si} \text { out of } \\
\text { solution) }\end{array}\end{array}$ & Not reported & 57 \\
\hline Bockris et al. & 1989 & PV-EC & $\begin{array}{l}\mathrm{Pt} @ \text { cathode } \\
\mathrm{RuO}_{2} @ \text { anode }\end{array}$ & Triple junction $\mathrm{Si}$ & 5 & $6 \mathrm{~h} ; \mathrm{STH}>4 \%$ & 58 \\
\hline $\begin{array}{l}\text { Gramaccioni, } \\
\text { Selvaggi and Galluzi }\end{array}$ & 1993 & PV-EC & $\begin{array}{l}\mathrm{Pt} @ \text { cathode } \\
\mathrm{RuO}_{2} @ \text { anode }\end{array}$ & Triple junction $\mathrm{Si}$ & $\sim 5$ & Not reported & 59 \\
\hline $\begin{array}{l}\text { Rocheleau, Miller and } \\
\text { Misra }\end{array}$ & 1998 & PV-EC & $\begin{array}{l}\text { CoMo @ cathode } \\
\text { NiFeO @ anode }\end{array}$ & Triple junction $\mathrm{Si}$ & 7.5 & $\begin{array}{l}\begin{array}{l}\text { 2h stable current in outdoor } \\
\text { test }\end{array} \\
\end{array}$ & 60 \\
\hline Khasalev, Turner & 1998 & Tandem PV-PEC & $\begin{array}{l}\text { Pt @ cathode } \\
\text { Pt @ anode }\end{array}$ & p-GaInP $2 / \mathrm{p} / \mathrm{n}-\mathrm{GaAs}$ & 12.4 & $\begin{array}{l}\text { Photocurrent decrease from } \\
120 \text { to } 105 \mathrm{~mA} / \mathrm{cm}^{2} \text { over } 20 \\
\mathrm{~h}\end{array}$ & 19 \\
\hline Grätzel et al. & 1999 & $\begin{array}{l}\text { Tandem } \\
\text { photoanode/PV }\end{array}$ & Pt @ cathode & $\mathrm{WO}_{3} / \mathrm{DSC}$ & 4.5 & Not reported & $24-27$ \\
\hline Licht et al. & 2000 & Tandem PV-PEC & $\begin{array}{l}\mathrm{Pt} @ \text { cathode } \\
\mathrm{RuO}_{2} @ \text { anode } \\
\end{array}$ & AlGaAs / p/n-Si & 18.3 & \begin{tabular}{|l|} 
Stable photocurrent over 14 \\
$\mathrm{~h}$
\end{tabular} & 21 \\
\hline Khasalev, Bansal and & 2001 & Tandem PV-PEC & Pt @ cathode & $\mathrm{p} / \mathrm{n}-\mathrm{GaInP}_{2} / \mathrm{p} / \mathrm{n}-\mathrm{GaAs}$ & 16.5 & 9h stable current in outdoor & 20 \\
\hline
\end{tabular}




\begin{tabular}{|c|c|c|c|c|c|c|c|}
\hline Turner & & & Pt @ anode & Double junction $\mathrm{Si}$ & & test & \\
\hline & & PV-EC & & Triple junction $\mathrm{Si}$ & 7.8 & Not reported & \\
\hline Grätzel et al. & 2001 & $\begin{array}{l}\text { Tandem } \\
\text { photoanode/PV }\end{array}$ & Pt @ cathode & $\mathrm{Fe}_{2} \mathrm{O}_{3} / \mathrm{DSC}$ & 2.2 & Not reported & $\begin{array}{l}25, \quad 27, \\
28\end{array}$ \\
\hline Ohmori et al. & 2003 & PV-EC & $\begin{array}{l}\text { CoMo@ cathode } \\
\text { FeNiO@ anode }\end{array}$ & Triple junction $\mathrm{Si}$ & 2.8 & $\begin{array}{l}\text { First } 30 \mathrm{~min} \text {; the efficiency } \\
\text { decreased to } 2.5 \% \text { and } \\
\text { remained for } 18 \mathrm{~h}\end{array}$ & 61 \\
\hline Park and Bard & 2005 & PV-EC & $\begin{array}{l}\text { Pt @ cathode } \\
\text { Pt @ anode }\end{array}$ & DSC / DSC / DSC & 3.7 & $\begin{array}{|lll|}9 \mathrm{~mA} / \mathrm{cm}^{2} & \text { stable current } \\
\text { after } 20 \mathrm{~h}\end{array}$ & 62 \\
\hline Kelly and Gibson & 2006 & PV-EC & $\begin{array}{l}\text { Pt or Ni @ cathode } \\
\text { Integrated FTO @ anode }\end{array}$ & Triple junction $\mathrm{Si}$ & $5-6$ & $\begin{array}{l}>31 \text { days of hydrogen } \\
\text { production }\end{array}$ & 22 \\
\hline $\begin{array}{l}\text { Peharz, Dimroth and } \\
\text { Wittstadt }\end{array}$ & 2007 & PV-PEC & $\begin{array}{l}\mathrm{Pt} @ \text { cathode } \\
\mathrm{IrO}_{2} @ \text { anode }\end{array}$ & $\mathrm{p} / \mathrm{n}-\mathrm{GaInAs} / \mathrm{p} / \mathrm{n}-\mathrm{GaInP}$ & 18 & $\begin{array}{l}2.3 \text { h stable current outdoor } \\
\text { test }\end{array}$ & 63 \\
\hline Imanishi et al. & 2009 & PV-EC & $\begin{array}{l}\mathrm{Pt} @ \text { cathode } \\
\mathrm{RuO}_{2} @ \text { anode } \\
\end{array}$ & $\mathrm{p}-\mathrm{CuI} / \mathrm{p} / \mathrm{n}-\mathrm{GaP}$ & 2.3 & 3h constant current & 64 \\
\hline Gaillard et al. & 2010 & Tandem PV-PEC & Pt @ cathode & $\mathrm{WO}_{3} / \mathrm{Si} \mathrm{PV}$ & 3.0 & Not reported & 65 \\
\hline Nocera et al. & 2011 & PV-EC & $\begin{array}{l}\text { NiMoZn @ cathode } \\
\text { ITO/amorphous Co @ } \\
\text { anode }\end{array}$ & Triple junction $\mathrm{Si}$ & $\begin{array}{l}4.7 \text { (wired) } \\
2.5 \text { (wireless) }\end{array}$ & $\begin{array}{l}\text { Stable for } 10 \mathrm{~h} \text { in } \mathrm{KB}_{\mathrm{i}} 1 \mathrm{~mol} \\
\mathrm{~L}^{-1} \text {, then } 20 \% \text { decrease over } \\
\text { next } 14 \mathrm{~h} \text {; stable for } 30 \mathrm{~h} \\
\text { using FTO instead of ITO }\end{array}$ & 33 \\
\hline Graetzel, Sivula et al. & 2012 & $\begin{array}{l}\text { Tandem } \\
\text { photoanode/PV- } \\
\text { PEC }\end{array}$ & Pt @ cathode & $\mathrm{WO}_{3} / \mathrm{DSC}$ & 3.1 & - & 23 \\
\hline Fujii et al. & 2013 & PV-EC & $\begin{array}{l}\text { Pt @ cathode } \\
\text { Pt @ anode }\end{array}$ & $\begin{array}{l}\mathrm{p} / \mathrm{n}-\mathrm{GaIn} / \mathrm{p} / \mathrm{n}-\mathrm{InGaAs} / \\
\mathrm{p} / \mathrm{n}-\mathrm{Ge}\end{array}$ & $\begin{array}{l}15 \text { (3 solar cells) } \\
12(1 \mathrm{PV})\end{array}$ & $\begin{array}{l}\text { 1h constant current and } \\
\text { hydrogen production }\end{array}$ & 66 \\
\hline
\end{tabular}




\begin{tabular}{|c|c|c|c|c|c|c|c|}
\hline Jacobsson et al. & 2013 & PV-PEC & $\begin{array}{l}\text { Pt @ cathode } \\
\text { Pt @ anode }\end{array}$ & p/n-CuInGaSe / 3 cells & 10 & $27 \mathrm{~h}$ & 53 \\
\hline van de Krol et al. & 2013 & Tandem PEC & $\begin{array}{l}\mathrm{Pt} @ \text { cathode } \\
\text { Co-P } \mathrm{P} @ \text { anode }\end{array}$ & $\begin{array}{l}\mathrm{BiVO}_{4} \\
\text { Double junction } \mathrm{Si}\end{array}$ & 3.6 & 1h stable photocurrent & 67 \\
\hline van de Krol et al. & 2013 & Tandem PEC & $\begin{array}{l}\text { Pt @ cathode } \\
\text { Co-P } \mathrm{P} @ \text { anode } \\
\end{array}$ & \begin{tabular}{|l|}
$\mathrm{BiVO}_{4}$ \\
Triple junction $\mathrm{Si}$ \\
\end{tabular} & 4.9 & $1 \mathrm{~h}$ & 67 \\
\hline Han et al. & 2014 & PV-PEC & \begin{tabular}{|ll} 
Pt@ $@$ cathode \\
Co-Pi @ anode
\end{tabular} & Si:h/Si:H/BiVO4 & 5,2 & $1 \mathrm{~h}<5 \%$ current loss & 68 \\
\hline Peng, Lee et al. & 2014 & Tandem PEC-PV & $\begin{array}{l}\text { Pt @ cathode } \\
\text { Au @ anode }\end{array}$ & $\begin{array}{l}\mathrm{Fe}_{2} \mathrm{O}_{3} / \mathrm{PV} \\
\text { Double junction } \mathrm{Si}\end{array}$ & 6.0 & 40 min measurement of $\mathrm{O}_{2}$ & 69 \\
\hline Segalman et al. & 2014 & PV-EC & $\begin{array}{l}\text { Pt @ cathode } \\
\text { Pt @ anode }\end{array}$ & $\begin{array}{l}\mathrm{p} / \mathrm{n}-\mathrm{GaInP}_{2} / \mathrm{p} / \mathrm{n}-\mathrm{GaAs} / \\
\mathrm{p} / \mathrm{n}-\mathrm{Ge}\end{array}$ & 6.2 & $15 \mathrm{~h}$ constant current density & 70 \\
\hline Nocera et al. & 2014 & PV-EC & $\begin{array}{l}\text { NiMoZn @ cathode } \\
\text { NiB @ anode }\end{array}$ & $\begin{array}{l}\text { Si minimodules side by } \\
\text { side }\end{array}$ & 10 & 168h constant efficiency & 34 \\
\hline Grätzel et al. & 2014 & Tandem PV & $\mathrm{NiFe} / \mathrm{Ni}$ foam electrodes & $\begin{array}{l}\text { Two } \mathrm{CH}_{3} \mathrm{NH}_{3} \mathrm{PbI}_{3} \mathrm{PVs} \\
\text { in series }\end{array}$ & 12.3 & \begin{tabular}{|lrl|} 
Decreased & \multicolumn{2}{c}{ photocurrent } \\
over 2 hour due to \\
instability of perovskite \\
solar cells
\end{tabular} & 30 \\
\hline Lewis et al. & 2014 & Tandem PV-PEC & Pt @ cathode & $\mathrm{WO}_{3} / \mathrm{Si}$ & 0.0068 & 10 min stable photocurrent & 36 \\
\hline Hwang, Min et al. & 2015 & PV-PEC & $\begin{array}{l}\mathrm{Au} @ \text { cathode } \\
\mathrm{Co}_{3} \mathrm{O}_{4} @ \text { anode }\end{array}$ & CuInGaSSe / PV & 4.23 & $\begin{array}{l}\text { Efficiency decreased to } \\
2.67 \% \text { after } 5 \mathrm{~h} \text {. }\end{array}$ & 71 \\
\hline Lewis et al. & 2015 & PEC & $\begin{array}{l}\text { Pt @ cathode } \\
\text { Pt @ anode }\end{array}$ & Si microwires / Nafion & $\sim 0.5$ & $2 \mathrm{~h}$ electrode operation & 72 \\
\hline Lewis et al. & 2015 & PEC & $\mathrm{NiO} @$ anode & $\mathrm{NiO}_{\mathrm{x}} / \mathrm{Si}$ & 2.1 to $\mathrm{O} 2$ (figure & $1200 \mathrm{~h}$ of $\mathrm{O}_{2}$ evolution & 73 \\
\hline
\end{tabular}




\begin{tabular}{|l|l|l|l|l|l|l|}
\hline & & & & of merit) & & \\
\hline
\end{tabular}

PV: Photovoltaics; PEC: Photoelectrochemical; DSC: Dye-Sensitized Solar Cell; ITO: indium tin oxide; KB i $_{\mathrm{i}}$ potassium borate; FTO: fluorine-doped tin oxide. This Table comprises most of the world-records of water-splitting devices with efficiencies $>2 \%$. 
A recent article has summarized both chromophore-catalyst assemblies and the interfacial dynamics involved in DSPEC water splitting. ${ }^{74}$ For $\mathrm{TiO}_{2}$ as the oxide semiconductor, the interfacial dynamics are not favorable. The results of transient absorption measurements on surface-bound assemblies show that back electron transfer following injection and intraassembly electron transfer, eqs 1-3, occurs on the $\mu$ sec timescale. Back electron transfer is typically rate limited by electron diffusion from the nanoparticles back to the interface. On the other hand, electron transfer migration through the microns thick oxide films to the TCO collector electrode in eq 4 occurs on the msec timescale. The unfavorable mismatch in rates ensures low efficiencies for the accumulation of oxidative equivalents at the catalyst and low efficiencies for water splitting.

$$
\begin{aligned}
& \text { FTO }\left|\mathrm{TiO}_{2}\right|-\left[\mathrm{Ru}_{\mathrm{a}}{ }^{\mathrm{II}}-\mathrm{Ru}_{\mathrm{b}}{ }^{\mathrm{II}}-\mathrm{OH}_{2}\right]^{4+} \stackrel{h v}{\longrightarrow} \quad \mathrm{FTO}^{4+} \mathrm{TiO}_{2} \mid-\left[\mathrm{Ru}_{\mathrm{a}}{ }^{\mathrm{II}} *-\mathrm{Ru}_{\mathrm{b}}{ }^{\mathrm{II}}-\mathrm{OH}_{2}\right]^{4+} \\
& \rightarrow \text { FTO }\left|\mathrm{TiO}_{2}\left(\mathrm{e}^{-}\right)\right|-\left[\mathrm{Ru}_{\mathrm{a}}{ }^{\mathrm{III}}-\mathrm{Ru}_{\mathrm{b}}{ }^{\mathrm{II}}-\mathrm{OH}_{2}\right]^{5+} \\
& \text { FTO }\left|\mathrm{TiO}_{2}\left(\mathrm{e}^{-}\right)\right|-\left[\mathrm{Ru}_{\mathrm{a}}{ }^{\mathrm{III}}-\mathrm{Ru}_{\mathrm{b}}{ }^{\mathrm{II}}-\mathrm{OH}_{2}\right]^{5+} \rightarrow \mathrm{FTO}\left|\mathrm{TiO}_{2}\left(\mathrm{e}^{-}\right)\right|-\left[\mathrm{Ru}_{\mathrm{a}}{ }^{\mathrm{II}}-\mathrm{Ru}_{\mathrm{b}}{ }^{\mathrm{III}}-\mathrm{OH}_{2}\right]^{5+} \\
& \text { FTO }\left|\mathrm{TiO}_{2}\left(\mathrm{e}^{-}\right)\right|-\left[\mathrm{Ru}_{\mathrm{a}}{ }^{\mathrm{II}}-\mathrm{Ru}_{\mathrm{b}}{ }^{\mathrm{III}}-\mathrm{OH}_{2}\right]^{5+} \rightarrow \mathrm{FTO}\left|\mathrm{TiO}_{2}\right|-\left[\mathrm{Ru}_{\mathrm{a}}{ }^{\mathrm{II}}-\mathrm{Ru}_{\mathrm{b}}{ }^{\mathrm{II}}-\mathrm{OH}_{2}\right]^{4+} \\
& \text { FTO }\left|\mathrm{TiO}_{2}\left(\mathrm{e}^{-}\right)\right|-\left[\mathrm{Ru}_{\mathrm{a}}{ }^{\mathrm{II}}-\mathrm{Ru}_{\mathrm{b}}{ }^{\mathrm{III}}-\mathrm{OH}_{2}\right]^{5+} \rightarrow \mathrm{FTO}\left(\mathrm{e}^{-}\right)|| \mathrm{TiO}_{2} \mid-\left[\mathrm{Ru}_{\mathrm{a}}{ }^{\mathrm{II}}-\mathrm{Ru}_{\mathrm{b}}{ }^{\mathrm{III}}-\mathrm{OH}_{2}\right]^{5+}
\end{aligned}
$$

To overcome this kinetic limitation, core/shell structures were introduced with cores of a nanoparticle TCO, nanoITO or nanoATO, and a thin, 3-5 nm, external shell of $\mathrm{TiO}_{2}$. In these structures, with the assembly bound to the $\mathrm{TiO}_{2}$ shell, injection is followed by rapid transfer through the shell to the conducting core. In the core/shell structure, injection and electron transfer to the core are competitive with back electron transfer resulting in per photon absorbed efficiencies approaching 5\% with monochromatic light. ${ }^{51}$ In a follow up study, efficiencies were increased by $\sim 5$ using a $\mathrm{SnO}_{2}$ core with back electron transfer from the core through the shell to the oxidized assembly inhibited by the more positive conduction band potential $(+0.4 \mathrm{~V})$ for $\mathrm{SnO}_{2}$ compared to $\mathrm{TiO}_{2}$.

The development of core/shell structures with ultrathin semiconducting shells to control interfacial dynamics was a key in the development of the DSPEC with a first report applied to water splitting in 2013. ${ }^{51,54}$ Significant progress has been made since with a variety of chromophore-catalyst assemblies under active investigation with water splitting as the initial target. An ultimate goal is tandem cells which integrate both photoanodes for water oxidation and photocathodes for $\mathrm{CO}_{2}$ reduction or bias-free water splitting. The targets for $\mathrm{CO}_{2}$ reduction are formate/formic acid or $\mathrm{H}_{2}$ : $\mathrm{CO}$ synthesis gas ('syngas') mixtures. When combined with Fischer-Tropsch synthesis, syngas is the feedstock for methanol and hydrocarbon production.

\subsection{DSPEC Design Strategies for Chromophore-Catalyst Assemblies:}

Figure 6 illustrates the structures of two chromophore-catalyst assemblies for water oxidation that have been investigated at the UNC EFRC. The assembly [(4,4'$\left.\left.\left(\mathrm{PO}_{3} \mathrm{H}_{2}\right)_{2} \mathrm{bpy}\right)_{2} \mathrm{Ru}^{\mathrm{II}}(\mathrm{bpm}) \mathrm{Ru}^{\mathrm{II}}(\mathrm{tpy})\left(\mathrm{OH}_{2}\right)\right]^{4+}$ (Figure 6A) was notable as a first example of a surface-bound assembly for electrocatalytic water oxidation with sustained water oxidation 
catalysis demonstrated in acidic solutions for at least 28,000 turnovers without decomposition at a rate of $0.6 \mathrm{~s}^{-1} .75$

A variety of chromophore-catalyst assembly strategies have been investigated. As shown in Figure 7, they include surface assembled structures including a molecular overlayer (Figure 7A), ${ }^{76}$ co-loaded (Figure 7E), ${ }^{77}$ layer-by-layer (Figure 7C), ${ }^{78-80}$ and electro-assembly structures (Figure $7 \mathrm{~B})^{81,82}$. They also include pre-formed assemblies based on peptide scaffolds (Figure 7D), ${ }^{85,86}$ and polymer scaffolds (Figure 7F), ${ }^{83,84}$ and covalently linked molecular assemblies (Figure $6 \mathrm{~A} \& \mathrm{~B}) .^{75,87-92}$. In the electro-assembly procedure, a phosphonate derivatized chromophore, also containing a vinyl-2,2'-bpy ligand or ligands, is surface-bound to the oxide. Reductive electrochemical scans with a vinyl-bpy containing water oxidation catalyst in the

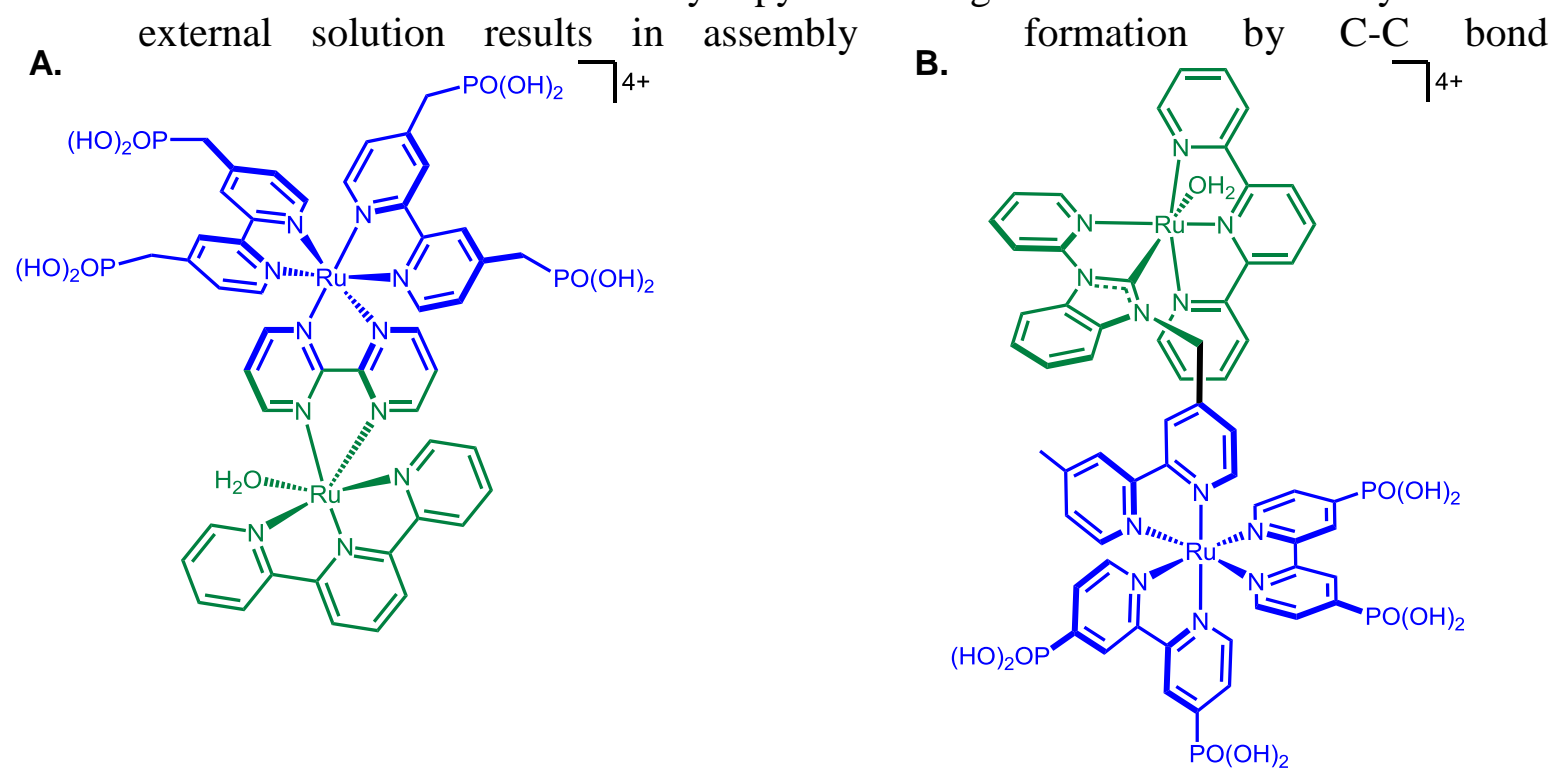

Figure 6. Examples of covalently-linked chromophore-catalyst assemblies: A) "Green Dimer" representing our initial example of a surface-bound assembly for water oxidation catalysis. B) RuCarbene chromophore/catalyst assembly for photocatalytic water oxidation. The chromophores are shown in blue and the catalysts in green.

formation. $^{93,94}$

The electro-assembly, electropolymerization procedure has been applied successfully to the preparation of both electropolymerized films for catalytic water oxidation ${ }^{82,95,96}$ and DSPEC photoanodes for light-driven water splitting in $\mathrm{TiO}_{2}$ nanoparticle films. ${ }^{97}$ In a recent example, we reported the preparation of electrocatalytically active polymeric films on both oxide and glassy carbon electrodes by electropolymerization of the vinyl-derivatized water oxidation catalyst, $\mathrm{Ru}^{\mathrm{II}}(2,2 \text { '-bipyridine-6,6'-dicarboxylicacid)(4-vinylpyridine })_{2} \quad\left(\mathrm{Ru}(\mathrm{bda})(4-\mathrm{vpy})_{2}\right) .^{98}$ Electropolymerization was carried out in acetonitrile solutions of the complex by a sequence of reductive potential scan cycles. The surface coverage of poly-Ru(bda)(4-vpy) ${ }_{2}$ varied linearly with the number of scan cycles illustrating an advantage of the electropolymerization technique in controlling film thickness and composition. As shown by rotating ring disc experiments (RRDE) with $\mathrm{O}_{2}$ generation at the disc and detection at the ring, at $\mathrm{pH} 7$ in a $0.1 \mathrm{M} \mathrm{H}_{2} \mathrm{PO}_{4}{ }^{-}$ $/ \mathrm{HPO}_{4}{ }^{2-}$ buffer, water oxidation in the electropolymerized films occurs with a turnover frequency (TOF) of $8.5 \mathrm{~mol} \mathrm{O}_{2}$ per catalyst site per second at an overpotential of $620 \mathrm{mV}$. Under these conditions, following oxidation of the catalyst to $\mathrm{Ru}^{\mathrm{V}}(\mathrm{O})^{+}$, rate limiting O---O bond formation is enhanced by the added buffer base by the use of Atom Proton Transfer (APT), eq 1, in which O- 
atom transfer to a water molecule occurs in concert with loss of a proton to an added base with B $=\mathrm{Ac}^{-}, \mathrm{HPO}_{4}{ }^{2-}$, etc. ${ }^{99}$



A chromophore-catalyst electro-assembly was prepared within the cavities of nanoparticle $\mathrm{TiO}_{2}$ films by reductive scans of surface-bound [Ru(5,5'-divinyl-2,2'-bipyridine $)_{2}$ (4,4'$\left.\left(\mathrm{PO}_{3} \mathrm{H}_{2}\right)_{2} \mathrm{bpy}\right)_{2}\left(\mathrm{RuP}\left(5,5^{\prime} \text {-vbpy }\right)_{2}{ }^{2+}\right)$ with $\mathrm{Ru}(\mathrm{bda})(4-\mathrm{vpy})_{2}$ in the external solution to give a $\mathrm{FTO} \mathrm{TiO}_{2} \mid-\mathrm{RuP}\left(5,5^{\prime} \text {-vbpy }\right)_{2}{ }^{2+}-\mathrm{Ru}(\mathrm{bda})(4-\mathrm{vpy})_{2}$ photoanode. Upon $100 \mathrm{~mW} \mathrm{~cm}{ }^{-2}$ white light illumination at $\mathrm{pH} 7$ in a $\mathrm{H}_{2} \mathrm{PO}_{4}{ }^{-} / \mathrm{HPO}_{4}{ }^{2-}$ buffer with a $0.2 \mathrm{~V}$ vs. SCE (saturated calomel electrode) bias, sustained photocurrents were observed over a several minute time period with $\mathrm{O}_{2}$ monitored by using a parallel generator-collector electrode design. ${ }^{98-101}$

\subsection{DSPEC Photoanode Design and Construction:}

$\mathrm{TiO}_{2}$ is an n-type semiconductor oxide and the most commonly used oxide in photoanode applications. It has a $\mathrm{pH}$-dependent conduction band potential in an appropriate range, $200 \mathrm{mV}$ vs. NHE at $\mathrm{pH} \mathrm{1,} \mathrm{well} \mathrm{developed} \mathrm{methods} \mathrm{of} \mathrm{synthesis} \mathrm{for} \mathrm{mesoporous} \mathrm{nanoparticle} \mathrm{films} \mathrm{are}$ available, and the films are stable. Semiconductor/liquid junctions are at the heart of a DSPEC, ${ }^{54}$ and with water as the solvent, semiconductor photoelectrodes must be stable under aqueous conditions. The need for aqueous stability limits the range of useful semiconductors with $\mathrm{Cu}_{2} \mathrm{O}$, $\mathrm{InP}$, and $\mathrm{ZnO}$, for example, unstable at the highly oxidative potentials required for water oxidation. $^{38,102-105}$

In an initial, preliminary DSPEC study, the photoelectrochemical response of the chromophore, $\left[\mathrm{Ru}(\mathrm{bpy})_{2}\left(4,4-\left(\mathrm{PO}_{3} \mathrm{H}_{2}\right)_{2} \mathrm{bpy}\right)_{2}\right]^{2+}\left(\mathrm{RuP}^{2+}\right)$ on $\mathrm{TiO}_{2}$ was investigated with triethanolamine or deprotonated EDTA (EDTA ${ }^{4-}$ ) added as irreversible reductive scavengers in the external solution. Following excitation and injection by the chromophore, FTO $\left|\mathrm{TiO}_{2}\right|-\mathrm{RuP}^{2+}$ $+\mathrm{hv} \rightarrow \mathrm{FTO}\left|\mathrm{TiO}_{2}\left(\mathrm{e}^{-}\right)\right|-\mathrm{RuP}^{3+}$, reduction of $-\mathrm{RuP}^{3+}$ by the reductive scavengers freed the injected electron for transfer to a cathode for $\mathrm{H}^{+}$reduction to $\mathrm{H}_{2}$. With an applied bias to maximize photocurrents, photocurrents and $\mathrm{H}_{2}$ production at the cathode were observed with efficiencies approaching $14.7 \%$ under steady-state irradiation. ${ }^{49,106}$

$\mathrm{Nb}_{2} \mathrm{O}_{5}$ nanocrystalline films functionalized with $\mathrm{RuP}^{2+}$ were also used as the photoanode in DSPECs for hydrogen generation. ${ }^{107}$ For a $\mathrm{T}$-phase orthorhombic $\mathrm{Nb}_{2} \mathrm{O}_{5}$ nanocrystalline film, the conduction band potential is slightly positive $(<0.1 \mathrm{eV})$ relative to anatase $\mathrm{TiO}_{2}$. Anatase $\mathrm{TiO}_{2}$ has a wide distribution of trap states including deep trap and band-tail trap states. Orthorhombic $\mathrm{Nb}_{2} \mathrm{O}_{5}$ is dominated by shallow band-tail trap states. Trap state distributions, conduction band energies, and interfacial barriers all appear to contribute to a slower back electron transfer rate, lower injection yield on the nanosecond time scale, and a lower opencircuit voltage $\left(\mathrm{V}_{\mathrm{oc}}\right)$, for $\mathrm{Nb}_{2} \mathrm{O}_{5}$ compared to anatase $\mathrm{TiO}_{2}$. In an operating DSPEC, with EDTA ${ }^{4-}$ added as a reductive scavenger, $\mathrm{H}_{2}$ quantum yield and photostability measurements show that $\mathrm{Nb}_{2} \mathrm{O}_{5}$ is comparable, but not superior, to $\mathrm{TiO}_{2}$ as a photoanode material. ${ }^{107}$ 
A.

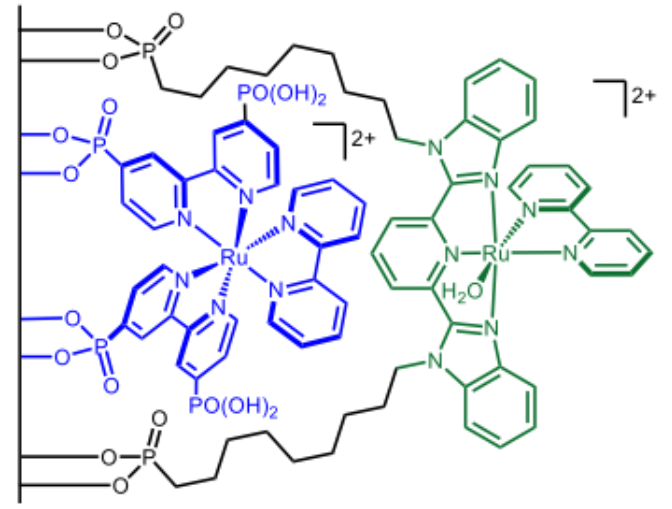

B.

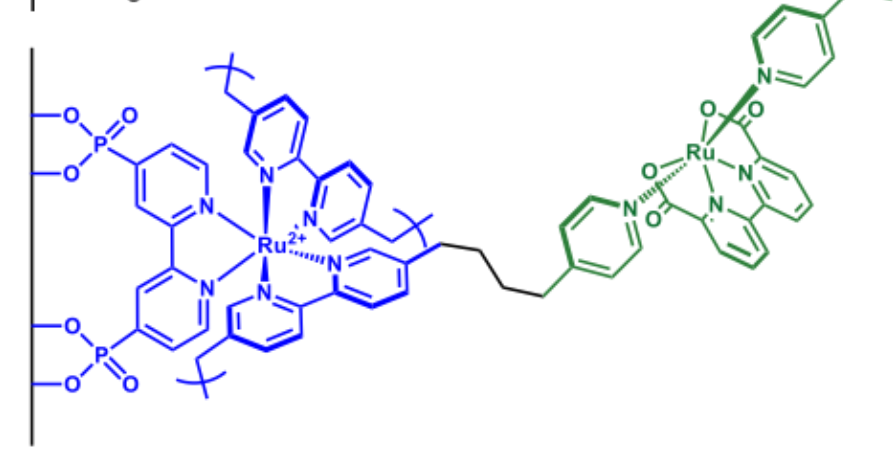

C.

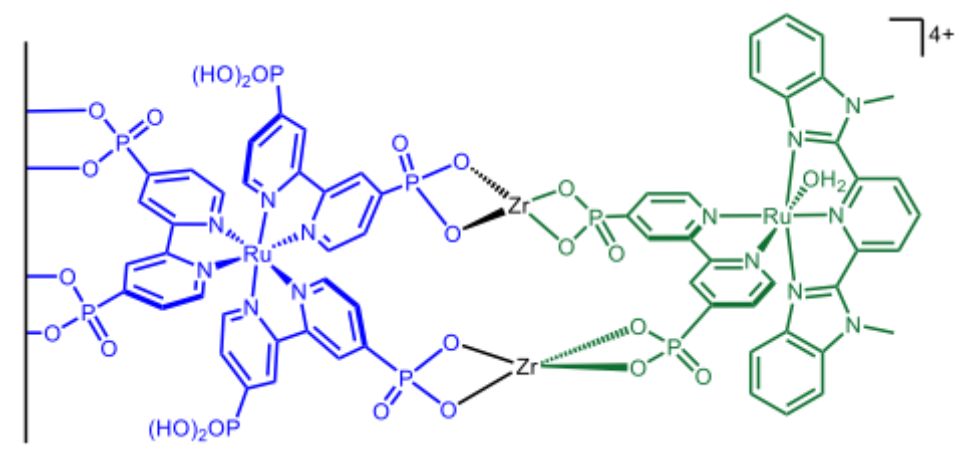

D.

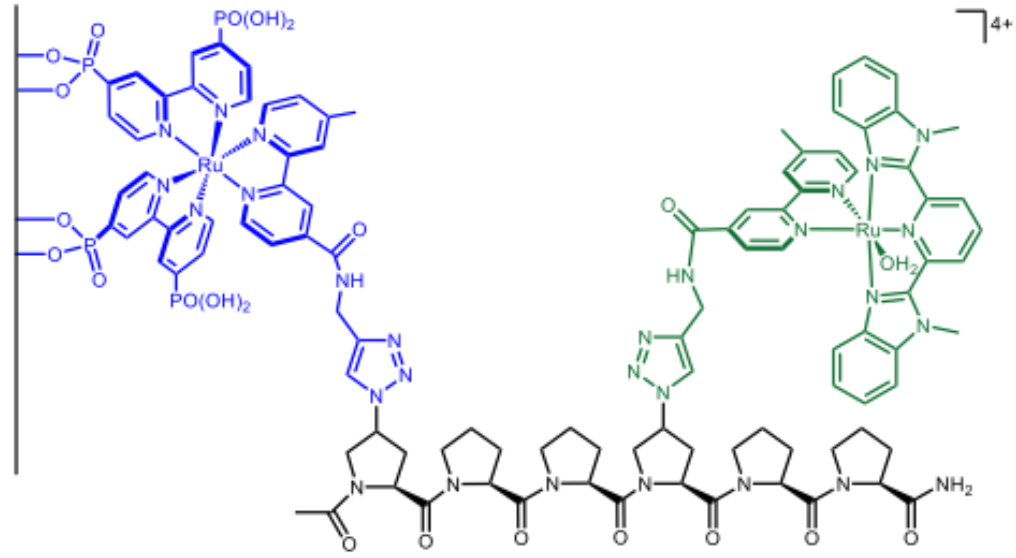

E.

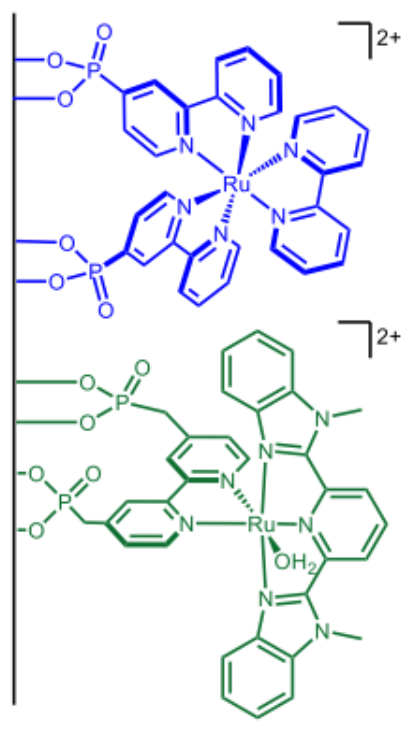

F.

chromophore chromophore



Figure 7. Examples of different strategies for bringing together chromophores and catalysts in close proximity on a surface: A) molecular overlayer strategy ${ }^{76}$; B) electro-assembly structures ${ }^{98}$; C) layerby-layer strategy ${ }^{78-80}$; D) peptide scaffold ${ }^{85,86}$; E) co-loaded assemblies ${ }^{77}$ and F) polymer scaffolds ${ }^{83,84}$. 
Atomic layer deposition (ALD) has played a major role in the evolution of the DSPEC in the UNC EFRC. ALD is a conformal, layer-by-layer gas phase technique. It has been used successfully for stabilizing phosphonate surface binding of chromophores, ${ }^{50,108}$ catalysts, ${ }^{109}$ and assemblies by depositing overlayers of $\mathrm{Al}_{2} \mathrm{O}_{3}$ or $\mathrm{TiO}_{2}$. ${ }^{110}$

ALD has also been used to fabricate nanostructured core/shell electrodes for both DSC ${ }^{111}$ and DSPEC applications with the core/shell used to control interfacial dynamics. ${ }^{51,54,110}$ Initial results were reported on a dye-sensitized solar cell with the N719 dye with TCO cores and thin shells of $\mathrm{TiO}_{2}$. Short-circuit current densities, open-circuit voltages, and back electron transfer lifetimes were all found to depend on $\mathrm{TiO}_{2}$ shell thickness. All increased up to 1.8-2.4 nm and then declined as the shell thickness was increased further. It was suggested that, as the shell layer was increased in thickness, low energy trap states appear with back electron transfer to Ru(III) becoming increasingly competitive with transport to the core, decreasing device efficiencies. ${ }^{51}$

Initial DSPEC water splitting experiments were conducted on core/shell structures with transparent conducting oxide cores of antimony-doped tin oxide ( $\mathrm{Sb}(\mathrm{V}): \mathrm{SnO}_{2}-$ nanoATO) or tin-doped indium oxide ( $\mathrm{Sn}(\mathrm{IV}): \mathrm{In}_{2} \mathrm{O}_{3}$ - nanoITO) with $3.6 \mathrm{~nm} \mathrm{TiO}_{2}$ shells. The core/shell oxides were derivatized with the assembly shown in Figure 6B to give the photoanode structures,

a.

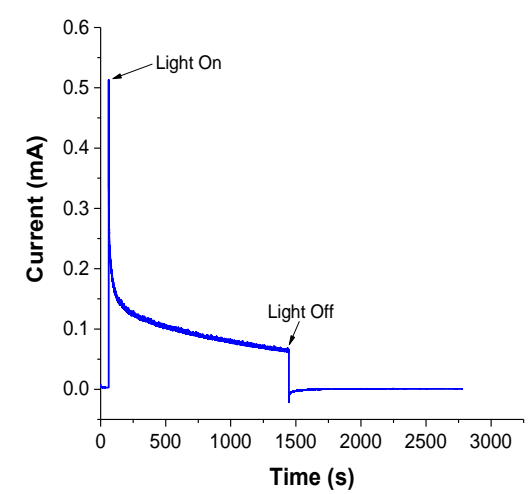

b.

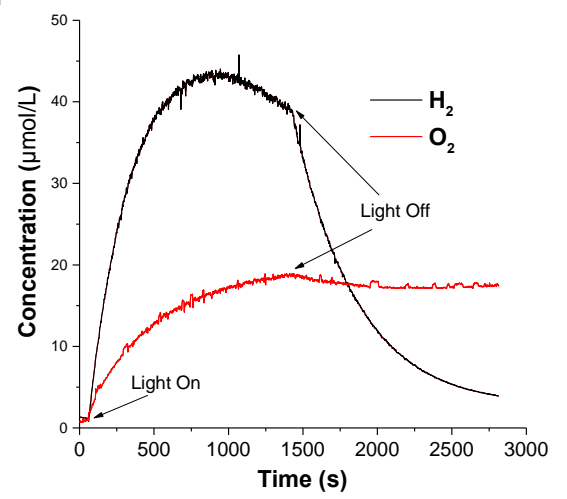

Figure 8. Photoelectrochemical water splitting by $\mathrm{FTO} \mathrm{SnO}_{2} / \mathrm{TiO}_{2}(6.6 \mathrm{~nm}) \mid-\left[\mathrm{Ru}_{\mathrm{a}}{ }^{\prime \prime}-\mathrm{Ru}_{\mathrm{b}}{ }_{\mathrm{b}}\right.$ $\left.\mathrm{OH}_{2}\right]^{4+}\left(0.3 \mathrm{nmAl}_{2} \mathrm{O}_{3}\right)$ with a $600 \mathrm{mV}$ applied bias in a $0.1 \mathrm{M} \mathrm{H}_{2} \mathrm{PO}_{4}^{-} / \mathrm{HPO}_{4}{ }^{2-}$ buffer at $\mathrm{pH} 7$ at room temperature. The assembly structure is shown in Figure 6B. A bias was applied across the working and counter electrodes in a two electrode configuration with the counter and reference leads both connected to the $\mathrm{Pt}$ counter electrode. The ionic strength was adjusted to $0.5 \mathrm{M}$ with $\mathrm{NaClO}_{4}$. Illumination was by a $46.2 \mathrm{~mW} / \mathrm{cm}^{2}, 455 \mathrm{~nm}$ LED: (a) Photocurrent-time trace and (b) $\mathrm{H}_{2}$ and $\mathrm{O}_{2}$ evolution time traces recorded in concert with the photocurrent trace.

FTO|nanoITO $\left|\mathrm{TiO}_{2}\right|-\left[\mathrm{Ru}^{\mathrm{II}}-\mathrm{Ru}^{\mathrm{II}}-\mathrm{OH}_{2}\right]^{4+}$. Photolysis in a $\mathrm{pH} 4.6$ acetate buffer with a Pt cathode resulted in water splitting with an absorbed photon conversion efficiency of $4.4 \%$ at peak photocurrent. $^{54}$

In a follow up study, DSPEC light-driven dehydrogenation of benzyl alcohol $(\mathrm{BnOH})$ to benzaldehyde and hydrogen was investigated on $\mathrm{TiO}_{2}$ and nanoITO/TiO 2 core/shells (nanoITO/TiO ${ }_{2}$ ) with co-surface bound chromophore $\mathrm{RuP}^{2+}$ and catalyst $\left[\mathrm{Ru}(\mathrm{Mebimpy})\left(\left(4,4^{\prime}-\right.\right.\right.$ $\left.(\mathrm{OH})_{2} \mathrm{P}(\mathrm{O}) \mathrm{CH}_{2}\right)_{2}$ bpy $\left.)\left(\mathrm{OH}_{2}\right)\right]^{2+}(\mathrm{Mebimpy}=2$,6-bis $(1-$ methylbenzimidazol-2-yl $)$ pyridine $)$. On these surfaces, chromophore excitation and electron injection are followed by cross surface electron-transfer activation of the catalyst to $\quad-\mathrm{Ru}(\mathrm{IV})=\mathrm{O}^{2+}$, which then oxidizes benzyl alcohol to benzaldehyde. At an optimized shell thickness, a sustained absorbed photon to current efficiency of $3.7 \%$ was achieved for $\mathrm{BnOH}$ dehydrogenation, an increase in efficiency of $\sim 10$ compared to n-type $\mathrm{TiO}_{2}{ }^{52}$ 
Follow-up DSPEC experiments have used cores of $\mathrm{SnO}_{2}$ in mesoporous $\mathrm{SnO}_{2} / \mathrm{TiO}_{2}$ core/shells derivatized with the assembly in Figure $6 \mathrm{~B} .{ }^{110}$ In this structure the $\sim 0.4 \mathrm{~V}$ more positive conduction band potential for $\mathrm{SnO}_{2}$ compared to $\mathrm{TiO}_{2}$ was exploited to create an uphill barrier to back electron transfer. Maximum photocurrents of $1.97 \mathrm{~mA} / \mathrm{cm}^{2}$ were obtained with $445 \mathrm{~nm}$ excitation. Direct monitoring of evolved $\mathrm{O}_{2}$ at the photoanode and $\mathrm{H}_{2}$ from the $\mathrm{Pt}$ cathode by in situ microelectrode analysis is shown in Figure 8. The relative ratios of $\mathrm{H}_{2}: \mathrm{O}_{2}$ provide direct evidence for water splitting and the enhanced efficiency a promising beginning to the design of future DSPEC prototypes for solar-driven water splitting.

\section{Reduction of $\mathrm{CO}_{2}$ in water to syngas mixtures:}

As part of the larger goal of DSPEC water splitting and $\mathrm{CO}_{2}$ reduction, significant progress has been made in the UNC EFRC on electrocatalyzed $\mathrm{CO}_{2}$ reduction. One target is synthesis gas or 'syngas', mixtures of $\mathrm{H}_{2}$ and $\mathrm{CO}$ that serve as important industrial feedstocks for methanol, acetic acid, ammonia, and hydrocarbons, the latter by Fischer-Tropsch synthesis. Solar driven production of syngas from $\mathrm{CO}_{2}$ and water could be important in the sustainable production of chemicals and fuels.

Electrochemical investigations into the mechanisms of $\mathrm{CO}_{2}$ to $\mathrm{CO}$ and of water to $\mathrm{H}_{2}$ by $\mathrm{Ru}(\mathrm{II})$ polypyridyl complexes in acetonitrile have provided detailed insight into how these

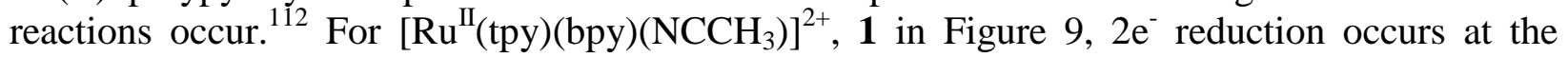
polypyridyl ligands activating the metal toward loss of bound $\mathrm{CH}_{3} \mathrm{CN}$ by $\mathrm{CO}_{2}$ to give the metallocarboxylate, $\left[\mathrm{Ru}(\mathrm{tpy})(\mathrm{bpy})\left(\mathrm{CO}_{2}\right)\right]$. The twice-reduced complex undergoes further reduction and $\mathrm{O}^{2-}$ loss to $\mathrm{CO}_{2}$ to give the corresponding $\mathrm{CO}$ complex. With added weak acids $\mathrm{H}_{2} \mathrm{O}, \quad \mathrm{H}_{2} \mathrm{PO}_{4}^{-}, \quad \mathrm{HCO}_{3}^{-}{ }^{-} \quad\left[\mathrm{Ru}(\mathrm{tpy})(\mathrm{bpy})\left(\mathrm{CO}_{2}\right)\right]$ is protonated to give the hydride, $\left[\mathrm{Ru}^{\mathrm{II}}(\mathrm{tpy})(\mathrm{bpy})(\mathrm{H})\right]^{+}$. Following reduction and protonation it releases $\mathrm{H}_{2}$. Electrolysis in the presence of both $\mathrm{CO}_{2}$ and added $\mathrm{H}_{2} \mathrm{PO}_{4}{ }^{-}$gave syngas mixtures of $\mathrm{H}_{2}$ and $\mathrm{CO}$ at ratios from 1:1 to 2:1 depending on the concentration of added acid.

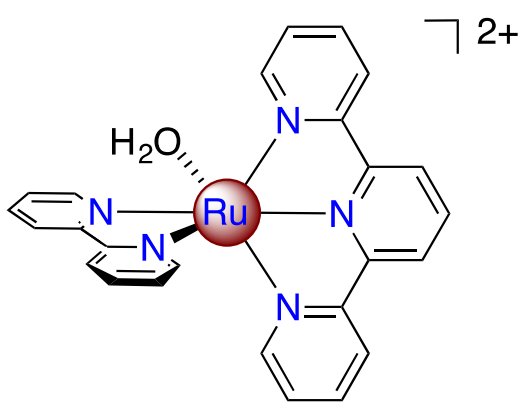

1

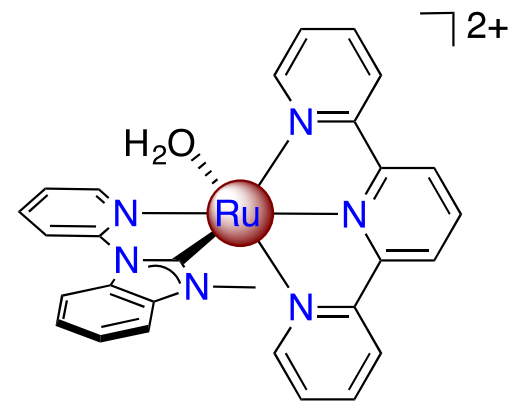

2

Figure 9. Structures of $\mathrm{Ru}(\mathrm{II})$ polypyridyl-aqua complex $\mathrm{CO}_{2}$ catalyst precursors 1 and 2.

The co-catalysis chemistry was extended to water with the complex [Ru ${ }^{\text {II }}(\mathrm{tpy})(\mathrm{Mebim}-$ py) $\left.\left(\mathrm{H}_{2} \mathrm{O}\right)\right]\left(\mathrm{PF}_{6}\right)_{2}$ (Mebim-py = 3-methyl-1-pyridyl-benzimidazol-2-ylidene, 2 in Figure 9). Electrochemical experiments demonstrated that catalyst 2 catalyzes both $\mathrm{CO}_{2}$ reduction to $\mathrm{CO}$ and water/proton reduction to $\mathrm{H}_{2}$ in aqueous $\mathrm{CO}_{2} / \mathrm{HCO}_{3}{ }^{-}$solutions with the product ratio adjustable by controlling the applied potential or the concentration of $\mathrm{HCO}_{3}{ }^{-113}$ 


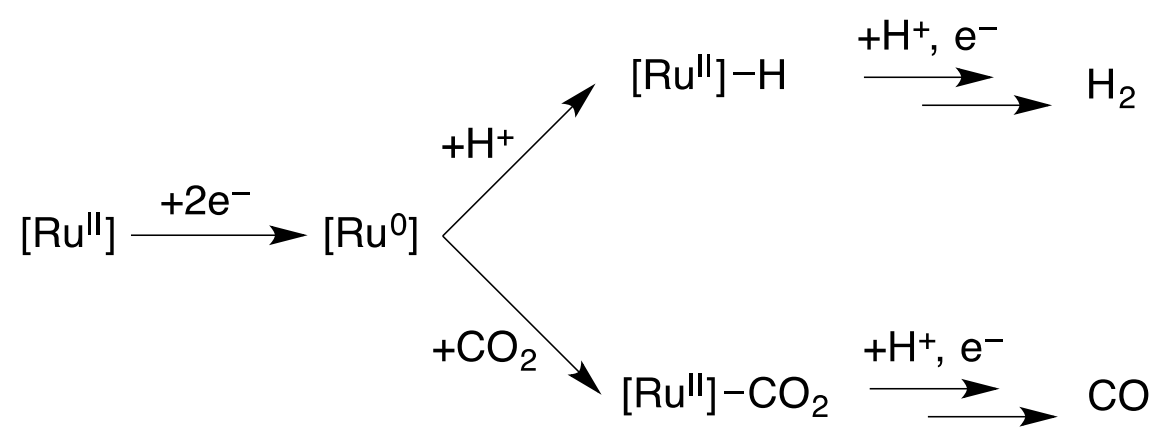

Figure 10. Pathways for syngas generation.

As shown by the mechanism in Figure 10, syngas generation occurs from a common intermediate. The product distribution in a $\mathrm{CO}_{2}$-saturated solution varies depending on the concentration of added acid and applied potential. Decreasing the potential from -1.2 to $-1.5 \mathrm{~V}$ increases the $\mathrm{H}_{2}$ : $\mathrm{CO}$ ratio from $0.5: 1$ to $3: 1$, and decreasing the $\mathrm{pH}$ from 7.2 to 6.5 increases the $\mathrm{H}_{2}$ :CO ratio from $0.5: 1$ to $4: 1$. Complex $\mathbf{1}$ is also a water oxidation catalyst ${ }^{114,115}$ and its use as a catalyst for both water oxidation and $\mathrm{CO}_{2}$ reduction in an $\mathrm{O}_{2} /$ syngas electrochemical cell has been demonstrated. ${ }^{116}$ An extension to surface-bound, high surface area electrodes is currently under investigation.

\section{Next step: Tandem DSPEC designs:}

In a tandem DSPEC design, a photoanode for water oxidation and photocathode for $\mathrm{CO}_{2}$ reduction are integrated in a single cell, separated by a proton exchange membrane. Target reactions for the two half-cells in a tandem DSPEC are water oxidation and $\mathrm{CO}_{2}$ reduction to either formate/formic acid or syngas, Scheme 1. In this design the two photoelectrodes utilize

\section{Scheme 1.}

Photoanode: $\quad 2 \mathrm{H}_{2} \mathrm{O}+4 \mathrm{~h} v \rightarrow \mathrm{O}_{2}+4 \mathrm{e}^{-}+4 \mathrm{H}^{+}$

Photocathode: $2 \mathrm{CO}_{2}+4 \mathrm{H}^{+}+4 \mathrm{e}^{-}+4 \mathrm{~h} v \rightarrow 2 \mathrm{H}_{2} \mathrm{O}+2 \mathrm{CO}$ or $2 \mathrm{CO}_{2}+4 \mathrm{H}^{+}+4 \mathrm{e}^{-}+4 \mathrm{~h} v \rightarrow 2 \mathrm{HCOOH}$

n-type semiconductor photoanodes $\left(\mathrm{TiO}_{2}, \mathrm{SnO}_{2}\right)$ for water oxidation and a p-type photocathode (NiO) for $\mathrm{CO}_{2}$ reduction. ${ }^{116-118}$ In a light efficient device, chromophore matching will be used to split the solar spectrum with different portions of the incident solar input absorbed by the two photoelectrodes. The most studied p-type semiconductor for DSC and DSPEC applications is $\mathrm{NiO}$ but the results of extensive studies have shown that $\mathrm{NiO}$ undergoes slow hole transport and unfavorable interfacial kinetics. In current research, core/shell $\mathrm{NiO}$ structures are currently under investigation as are the development of other oxide p-type materials.

\section{Looking to the Future. Outlook:}

The development of the DSPEC is a promising step forward with potential applications to solar fuels. Although likely to be at least a decade away from widespread use, niche markets exist that could benefit from initial prototypes. Because it is a solar-driven electrochemical approach, 
DSPEC panels for solar fuels can be deployed under ambient solar conditions anywhere there is sunlight. This concept of decentralized energy storage and production has implications for military forward operating bases, off-grid communities, island nations, and remote regions in the third world. There may even be early markets in the US where there are communities that pay $275 \%$ of the national average for their energy (Table 2) ${ }^{119}$ including island communities in Hawaii and the Virgin Islands and remote communities in Alaska and indigenous communities including parts of the Navajo, Yurok, and Lakota Nations.

Initial results are available which assess the potential for market entry and large-scale development. A study by Newman et al., examines federal government guarantees for the purchase of synthetic diesel fuel to supply the military with the cost of making diesel electrochemically comparable to petroleum as a starting material. ${ }^{11}$ Demand by the US Air Force and Navy is $\sim 80 \%$ of the total demand and equivalent to $\sim 26.8 \mathrm{GW}$ or 395,000 barrels of oil equivalent per day (BOE/day). Although promising as markets, these opportunities will only become viable as the technoeconomics become cost competitive. There are potentially viable strategies on a short timescale. For example, PV or wind turbines could be used to power electrochemical water splitting or $\mathrm{CO}_{2}$ reduction to syngas, $\mathrm{H}_{2}: \mathrm{CO}$ mixtures. $\mathrm{CO}_{2}$ is available as a byproduct of cement plants and, potentially from power plant flue gas with capture by amine scrubbers. Long distance $\mathrm{CO}_{2}$ pipelines already exist to supply the oil and gas industry, which could help minimize the need for new infrastructure. ${ }^{11}$ In the long term, $\mathrm{CO}_{2}$ capture as it is produced for solar recycling would provide a basis for closed cycles with minimal emissions and environmental impact.

Table 2. Comparison of the cost of energy between the national average and areas that pay up to $275 \%$ more than this average.

\begin{tabular}{|c|c|c|}
\hline Fuel & National Average & $\begin{array}{l}275 \% \text { of national } \\
\text { average per unit cost } \\
\text { benchmark }\end{array}$ \\
\hline Electricity & $\$ 0.12$ per $\mathrm{kWh}$ & $\$ 0.33$ per $\mathrm{kWh}$ \\
\hline Natural Gas & $\begin{array}{l}\begin{array}{l}\$ 12.18 \text { per thousand } \\
\text { cubic feet }\end{array} \\
\end{array}$ & $\begin{array}{l}\$ 30.50 \text { per thousand } \\
\text { cubic feet }\end{array}$ \\
\hline Fuel Oil & $\$ 2.42$ per gallon & $\$ 6.68$ per gallon \\
\hline LPG/Propane & $\$ 2.09$ per gallon & $\$ 5.76$ per gallon \\
\hline $\begin{array}{l}\text { Total Household Energy } \\
\text { cost per BTUs }\end{array}$ & $\$ 22.59$ per million BTUs & \$62.12 per million BTUs \\
\hline
\end{tabular}

At present, steadily decreasing costs for wind and PV make them less expensive than direct solar-to-fuel conversion in photoelectrochemical cells. In a technoeconomic analysis by Newman et al., the cost of producing $\mathrm{H}_{2}$ with wind was $\$ 3.64 / \mathrm{kg}, \$ 7.62 / \mathrm{kg}$ with $\mathrm{PV}$. The cost with existing PEC approaches exceeded $\$ 100 / \mathrm{kg}$. To become cost competitive, the lifetime of a PEC 
would have to be extended to 25 years with an energy efficiency of $~ 15 \%$. Much of the research in PECs is still fundamental and at the lab scale but recent progress augurs well for the future. Further research progress is needed with extension to translation and scale up. Much remains to be done, but significant progress has been made and the path forward is promising.

\section{Acknowledgements:}

This review of artificial photosynthesis is supported primarily by the UNC EFRC: Center for Solar Fuels, an Energy Frontier Research Center funded by the U.S. Department of Energy, Office of Science, Office of Basic Energy Sciences under Award Number DE-SC0001011. The review and tabulation of solar-to-fuel efficiency records by R.L.C. is supported by Fundação de Amparo à Pesquisa do Estado de São Paulo (FAPESP). The review of photoelectrochemical cell research by N.Y.M.I is supported by Conselho Nacional de Desenvolvimento Científico e Tecnológico (CNPq/CTEnerg).

\section{References:}

(1) Poverty: Not always with us. In The Economist, 2013.

(2) International Energy Agency "World Energy Outlook (Executive Summary)," 2014.

(3) Krupp, F. Don't Just Drill, Baby - Drill Carefully. In Foreign Affairs, 2014; pp 15.

(4) Inman, M. Natural Gas: The Fracking Fallacy. In Nature: News Feature, 2014.

(5) Patzek, T. W.; Male, F.; Marder, M. 2013. "Gas Production In The Barnett Shale Obeys A Simple Scaling Theory" Proceedings of the National Academy of Sciences U S A 110 (49): 19731.

(6) Davenport, C. Optimism Faces Grave Realities at Climate Talks. In New York Times, 2014.

(7) Folger, T. Rising Seas. In National Geographic, 2013.

(8) Climate Diplomacy: Flexible or Toothless? In The Economist, 2014.

(9) U. S. Department of Energy "Grid Energy Storage," 2013.

(10) Cardwell, D. Solar and Wind Energy Start to Win on Price vs. Conventional Fuels. In New York Times, 2014.

(11) Newman, J.; Hoertz, P. G.; Bonino, C. A.; Trainham, J. A. 2012. "Review: An Economic Perspective on Liquid Solar Fuels" Journal of the Electrochemical Society 159 (10): A1722.

(12) Energy Storage Update "US Energy Storage Technology Outlook," 2015.

(13) Fujishima, A.; Honda, K. 1971. "Electrochemical Evidence for the Mechanism of the Primary Stage of Photosynthesis" Bulletin of the Chemical Society of Japan 44: 1148.

(14) Fujishima, A.; Honda, K. 1972. "Electrochemical Photolysis of Water at a Semiconductor Electrode" Nature 238 (5358): 37.

(15) Walter, M. G.; Warren, E. L.; McKone, J. R.; Boettcher, S. W.; Mi, Q. X.; Santori, E. A.; Lewis, N. S. 2010. "Solar Water Splitting Cells" Chemical Reviews 110 (11): 6446.

(16) Heller, A. 1981. "Conversion of Sunlight into Electrical-Power and Photoassisted Electrolysis of Water in Photoelectrochemical Cells" Accounts of Chemical Research 14 (5): 154.

(17) Aharon-Shalom, E.; Heller, A. 1982. "Efficient p-InP (Rh-H alloy) and p-InP (Re-H alloy) Hydrogen Evolving Photocathodes" Journal of the Electrochemical Society 129: 2865. 
(18) Kainthla, R. C.; Zelenay, B.; Bockris, J. O.1987. "Significant Efficiency Increase in SelfDriven Photoelectrochemical Cell for Water Photoelectrolysis" Journal of the Electrochemical Society 134 (4): 841.

(19) Khaselev, O.; Turner, J. A. 1998. "A Monolithic Photovoltaic-Photoelectrochemical Device For Hydrogen Production Via Water Splitting" Science 280 (5362): 425.

(20) Khaselev, O.; Bansal, A.; Turner, J. A. 2001. "High-Efficiency Integrated Multijunction Photovoltaic/Electrolysis Systems For Hydrogen Production" International Journal of Hydrogen Energy 26 (2): 127.

(21) Licht, S.; Wang, B.; Mukerji, S.; Soga, T.; Umeno, M.; Tributsch, H. 2000. "Efficient


Physical Chemistry B 104 (38): 8920.

(22) Kelly, N. A.; Gibson, T. L. 2006. "Design And Characterization Of A Robust Photoelectrochemical Device To Generate Hydrogen Using Solar Water Splitting" International Journal of Hydrogen Energy 31 (12): 1658.

(23) Brillet, J.; Yum, J. H.; Cornuz, M.; Hisatomi, T.; Solarska, R.; Augustynski, J.; Graetzel, M.; Sivula, K. 2012. "Highly Efficient Water Splitting By A Dual-Absorber Tandem Cell" Nature Photonics 6 (12): 824.

(24) Grätzel, M. 1999. "The Artificial Leaf, Bio-Mimetic Photocatalysis" CATTEC 3: 4.

(25) Grätzel, M. 2001. "Photoelectrochemical Cells" Nature 414 (6861): 338.

(26) Santato, C.; Ulmann, M.; Augustynski, J. 2001. "Photoelectrochemical Properties Of Nanostructured Tungsten Trioxide Films" Journal of Physical Chemistry B 105 (5): 936.

(27) Grätzel, M.; Augustynski, J. Tandem Cell for Water Cleavage by Visible Light; Ecole Polytechnique Federale De Lausanne, 2005; Vol. PCT/EP2000/006350.

(28) Khan, S. U. M.; Akikusa, J. 1999. "Photoelectrochemical Splitting Of Water At Nanocrystalline n- $\mathrm{Fe}_{2} \mathrm{O}_{3}$ Thin-Film Electrodes" Journal of Physical Chemistry B 103 (34): 7184.

(29) Brillet, J.; Cornuz, M.; Le Formal, F.; Yum, J. H.; Gratzel, M.; Sivula, K. 2010. "Examining Architectures Of Photoanode-Photovoltaic Tandem Cells For Solar Water Splitting" Journal of Materials Research 25 (1): 17.

(30) Luo, J. S.; Im, J. H.; Mayer, M. T.; Schreier, M.; Nazeeruddin, M. K.; Park, N. G.; Tilley, S. D.; Fan, H. J.; Gratzel, M. 2014. "Water Photolysis At 12.3\% Efficiency Via Perovskite Photovoltaics And Earth-Abundant Catalysts" Science 345 (6204): 1593.

(31) Yang, X. G.; Liu, R.; He, Y. M.; Thorne, J.; Zheng, Z.; Wang, D. W. 2015. "Enabling Practical Electrocatalyst-Assisted Photoelectron-Chemical Water Splitting With Earth Abundant Materials" Nano Research 8(1): 56.

(32) Zou, X.; Zhang, Y. 2015. "Noble Metal-Free Hydrogen Evolution Catalysts For Water Splitting" Chemical Society Reviews Advance Article

(33) Reece, S. Y.; Hamel, J. A.; Sung, K.; Jarvi, T. D.; Esswein, A. J.; Pijpers, J. J. H.; Nocera, D. G. 2011. "Wireless Solar Water Splitting Using Silicon-Based Semiconductors and Earth-Abundant Catalysts" Science 334 (6056): 645.

(34) Cox, C. R.; Lee, J. Z.; Nocera, D. G.; Buonassisi, T. 2014. "Ten-Percent Solar-To-Fuel Conversion With Nonprecious Materials" Proceedings of the National Academy of Sciences US A 111 (39): 14057.

(35) McDonald, M. B.; Ardo, S.; Lewis, N. S.; Freund, M. S. 2014. "Use of Bipolar Membranes for Maintaining Steady-State $\mathrm{pH}$ Gradients in Membrane-Supported, Solar-Driven Water Splitting Michael" Chemsuschem 7 (11): 3021. 
(36) Shaner, M. R.; Fountaine, K. T.; Ardo, S.; Coridan, R. H.; Atwater, H. A.; Lewis, N. S. 2014. "Photoelectrochemistry Of Core-Shell Tandem Junction N-P(+)-Si/N-WO 3 Microwire Array Photoelectrodes" Energy \& Environmental Science 7 (2): 779.

(37) Ager, J. W.; Shaner, M. R.; Walczak, K. A.; Sharp, I. D.; Ardo, S. 2015. "Experimental Demonstrations of Spontaneous, Solar-Driven Photoelectrochemical Water Splitting" Energy \& Environmental Science (Accepted)

(38) Hu, S.; Shaner, M. R.; Beardslee, J. A.; Lichterman, M.; Brunschwig, B. S.; Lewis, N. S. 2014. "Amorphous $\mathrm{TiO}_{2}$ Coatings Stabilize Si, Gaas, And Gap Photoanodes For Efficient Water Oxidation" Science 344: 1005.

(39) Lichterman, M. F.; Carim, A. I.; McDowell, M. T.; Hu, S.; Gray, H. B.; Brunschwig, B. S.; Lewis, N. S. 2014. "Stabilization of n-Cadmium Telluride Photoanodes For Water Oxidation to $\mathrm{O}_{2}(\mathrm{G})$ In Aqueous Alkaline Electrolytes Using Amorphous $\mathrm{TiO}_{2}$ Films Formed By AtomicLayer Deposition" Energy \& Environmental Science 7 (10): 3334.

(40) Liu, R.; Zheng, Z.; Spurgeon, J.; Yang, X. G. 2014. "Enhanced Photoelectrochemical Water-Splitting Performance Of Semiconductors By Surface Passivation Layers" Energy \& Environmental Science 7 (8): 2504.

(41) Shaner, M. R.; Hu, S.; Sun, K.; Lewis, N. S. 2015. "Stabilization of Si Microwire Arrays For Solar-Driven $\mathrm{H}_{2} \mathrm{O}$ Oxidation to $\mathrm{O}_{2}(\mathrm{G})$ In $1.0 \mathrm{M} \mathrm{KOH}(\mathrm{Aq})$ Using Conformal Coatings of Amorphous $\mathrm{TiO}_{2}$ " Energy \& Environmental Science 8 (1): 203.

(42) Osterloh, F. E. 2013. "Inorganic Nanostructures for Photoelectrochemical and Photocatalytic Water Splitting" Chemical Society Reviews 42 (6): 2294.

(43) Hisatomi, T.; Kubota, J.; Domen, K. 2014. "Recent Advances in Semiconductors for Photocatalytic and Photoelectrochemical Water Splitting" Chemical Society Reviews 43 (22): 7520 .

(44) Wang, T.; Luo, Z. B.; Li, C. C.; Gong, J. L. 2014. "Controllable Fabrication of Nanostructured Materials For Photoelectrochemical Water Splitting via Atomic Layer Deposition" Chemical Society Reviews 43 (22): 7469.

(45) Jiao, Y.; Zheng, Y.; Jaroniec, M.; Qiao, S. Z. 2015. "Design of Electrocatalysts for Oxygen- and Hydrogen-Involving Energy Conversion Reactions" Chemical Society Reviews 44: 2060 .

(46) Ronge, J.; Bosserez, T.; Martel, D.; Nervi, C.; Boarino, L.; Taulelle, F.; Decher, G.; Bordiga, S.; Martens, J. A. 2014. "Monolithic Cells For Solar Fuels" Chemical Society Reviews 43 (23): 7963.

(47) Fenwick, A. Q.; Gregoire, J. M.; Luca, O. R. 2014. "Electrocatalytic Reduction of Nitrogen and Carbon Dioxide to Chemical Fuels: Challenges and Opportunities for a Solar Fuel Device." Journal of Photochemistry and Photobiology B 14: S1011.

(48) Brennaman, M. K.; Patrocinio, A. O. T.; Song, W. J.; Jurss, J. W.; Concepcion, J. J.; Hoertz, P. G.; Traub, M. C.; Iha, N. Y. M.; Meyer, T. J. 2011. "Interfacial Electron Transfer Dynamics Following Laser Flash Photolysis of $\mathrm{Ru}(\mathrm{bpy})_{2}\left(\left(4,4 \text { '- } \mathrm{PO}_{3} \mathrm{H}_{2}\right)_{2} \mathrm{bpy}\right)^{2+}$ in $\mathrm{TiO}_{2}$ Nanoparticle Films in Aqueous Environments" Chemsuschem 4 (2): 216.

(49) Song, W.; Chen, Z.; Brennaman, M. K.; Concepcion, J.; Meyer, T. J. 2011. "Making Solar Fuels by Artificial Photosynthesis. " Pure and Applied Chemistry 83 (4): 749.

(50) Hanson, K.; Losego, M. D.; Kalanyan, B.; Parsons, G. N.; Meyer, T. J. 2013. "Stabilizing Small Molecules on Metal Oxide Surfaces Using Atomic Layer Deposition" Nano Letters 13 (10): 4802 . 
(51) Alibabaei, L.; Farnum, B. H.; Kalanyan, B.; Brennaman, K.; Losego, M. D.; Parsons, G. N.; Meyer, T. J. 2014. "Atomic Layer Deposition of $\mathrm{TiO}_{2}$ on Mesoporous nanoITO: Conductive Core-Shell Photoanodes for Dye-Sensitized Solar Cells" Nano Letters 14 (6): 3255.

(52) Song, W.; Vannucci, A. K.; Farnum, B. H.; Lapides, A. M.; Brennaman, M. K.;

Kalanyan, B.; Alibabaei, L.; Concepcion, J. J.; Losego, M. D.; Parsons, G. N.; Meyer, T. J. 2014.

"Visible Light Driven Benzyl Alcohol Dehydrogenation in a Dye-Sensitized

Photoelectrosynthesis Cell" Journal of the American Chemical Society 136 (27): 9773.

(53) Jacobsson, T. J.; Fjallstrom, V.; Sahlberg, M.; Edoff, M.; Edvinsson, T. 2013. "A

Monolithic Device for Solar Water Splitting Based On Series Interconnected Thin Film

Absorbers Reaching Over 10\% Solar-To-Hydrogen Efficiency" Energy \& Environmental

Science 6 (12): 3676.

(54) Alibabaei, L.; Brennaman, M. K.; Norris, M. R.; Kalanyan, B.; Song, W.; Losego, M. D.; Concepcion, J. J.; Binstead, R. A.; Parsons, G. N.; Meyer, T. J. 2013. "Solar Water Splitting in a Molecular Photoelectrochemical Cell" Proceedings of the National Academy of Sciences U S A 110 (50): 20008.

(55) Berardi, S.; Drouet, S.; Francas, L.; Gimbert-Surinach, C.; Guttentag, M.; Richmond, C.; Stoll, T.; Llobet, A. 2014. "Molecular Artificial Photosynthesis" Chemical Society Reviews 43 (22): 7501.

(56) Appleby, A. J.; Delahoy, A. E.; Gau, S. C.; Murphy, O. J.; Kapur, M.; Bockris, J. O. M. 1985. "An Amorphous Silicon-Based One-Unit Photovoltaic Electrolyzer" Energy 10 (7): 871.

(57) Sakai, Y.; Sugahara, S.; Matsumura, M.; Nakato, Y.; Tsubomura, H. 1988.

"Photoelectrochemical Water Splitting by Tandem Type and Heterojunction Amorphous-Silicon Electrodes" Canadian Journal of Chemistry-Revue Canadienne De Chimie 66 (8): 1853.

(58) Lin, G. H.; Kapur, M.; Kainthla, R. C.; Bockris, J. O. 1989. "One-Step Method to Produce Hydrogen by a Triple Stack Amorphous-Silicon Solar-Cell" Applied Physics Letters 55 (4): 386.

(59) Gramaccioni, C.; Selvaggi, A.; Galluzzi, F. 1993. "Thin-Film Multijunction Solar-Cell for Water Photoelectrolysis" Electrochimica Acta 38 (1): 111.

(60) Rocheleau, R. E.; Miller, E. L.; Misra, A. 1998. "High-Efficiency Photoelectrochemical Hydrogen Production Using Multijunction Amorphous Silicon Photoelectrodes" Energy \& Fuels $12(1): 3$.

(61) Yamada, Y.; Matsuki, N.; Ohmori, T.; Mametsuka, H.; Kondo, M.; Matsuda, A.; Suzuki, E. 2003. "One Chip Photovoltaic Water Electrolysis Device" International Journal of Hydrogen Energy 28 (11): 1167.

(62) Park, J. H.; Bard, A. J. 2005. "Unassisted Water Splitting From Bipolar Pt/DyeSensitized $\mathrm{TiO}_{2}$ Photoelectrode Arrays" Electrochemical and Solid State Letters 8 (12): G371. (63) Peharz, G.; Dimroth, F.; Wittstadt, U. 2007. "Solar Hydrogen Production by Water Splitting with a Conversion Efficiency of 18\%" International Journal of Hydrogen Energy 32 (15): 3248 .

(64) Yamane, S.; Kato, N.; Kojima, S.; Imanishi, A.; Ogawa, S.; Yoshida, N.; Nonomura, S.; Nakato, Y. 2009. "Efficient Solar Water Splitting with a Composite " $n-\mathrm{Si} / p-\mathrm{CuI} / n-i-p$ a-Si $/ n-p$ $\mathrm{GaP} / \mathrm{RuO}_{2}$ " Semiconductor Electrode" Journal of Physical Chemistry C 113 (32): 14575.

(65) Gaillard, N.; Chang, Y.; Kaneshiro, J.; Deangelis, A.; Miller, E. L. 2010. "Status of Research on Tungsten Oxide-based Photoelectrochemical Devices at the University of Hawai'i" Solar Hydrogen and Nanotechnology V 7770: 14. 
(66) Fujii, K.; Nakamura, S.; Sugiyama, M.; Watanabe, K.; Bagheri, B.; Nakano, Y. 2013. "Characteristics Of Hydrogen Generation From Water Splitting By Polymer Electrolyte Electrochemical Cell Directly Connected With Concentrated Photovoltaic Cell" International Journal of Hydrogen Energy 38 (34): 14424.

(67) Abdi, F. F.; Han, L. H.; Smets, A. H. M.; Zeman, M.; Dam, B.; van de Krol, R. 2013. "Efficient Solar Water Splitting By Enhanced Charge Separation In A Bismuth Vanadate-Silicon Tandem Photoelectrode" Nature Communications 4: 7.

(68) Han, L. H.; Abdi, F. F.; van de Krol, R.; Liu, R.; Huang, Z. Q.; Lewerenz, H. J.; Dam, B.; Zeman, M.; Smets, A. H. M. 2014. "Efficient Water-Splitting Device Based on a Bismuth Vanadate Photoanode and Thin-Film Silicon Solar Cells" Chemsuschem 7 (10): 2832.

(69) Wang, X.; Peng, K. Q.; Hu, Y.; Zhang, F. Q.; Hu, B.; Li, L.; Wang, M.; Meng, X. M.; Lee, S. T. 2014. "Silicon/Hematite Core/Shell Nanowire Array Decorated with Gold Nanoparticles for Unbiased Solar Water Oxidation" Nano Letters 14 (1): 18.

(70) Modestino, M. A.; Walczak, K. A.; Berger, A.; Evans, C. M.; Haussener, S.; Koval, C.; Newman, J. S.; Ager, J. W.; Segalman, R. A. 2014. "Robust Production of Purified $\mathrm{H}_{2}$ in a Stable, Self-Regulating, and Continuously Operating Solar Fuel Generator" Energy \& Environmental Science 7 (1): 297.

(71) Jeon, H. S.; Koh, J. H.; Park, S. J.; Jee, M. S.; Ko, D. H.; Hwang, Y. J.; Min, B. K. 2015. "A Monolithic and Standalone Solar-Fuel Device Having Comparable Efficiency to Photosynthesis in Nature" Journal of Materials Chemistry A 3 (11): 5835.

(72) Ardo, S.; Park, S. H.; Warren, E. L.; Lewis, N. S. 2015. "Unassisted Solar-Driven Photoelectrosynthetic HI Splitting Using Membrane-Embedded Si Microwire Arrays" Energy \& Environmental Science 8: 1484.

(73) Sun, K.; McDowell, M. T.; Nielander, A. C.; Hu, S.; Shaner, M. R.; Yang, F.; Brunschwig, B. S.; Lewis, N. S. 2015. "Stable Solar-Driven Water Oxidation to $\mathrm{O}_{2}$ (g) by NiOxide-Coated Silicon Photoanodes" Journal of Physical Chemistry Letters 6 (4): 592.

(74) Ashford, D.; Gish, M. K.; Vannucci, A. K.; Brennaman, M. K.; Templeton, J. L.; Papanikolas, J. M.; Meyer, T. J. 2015. "Molecular Chromophore-Catalyst Assemblies for Solar Fuel Applications" Chemical Reviews (Submitted)

(75) Concepcion, J. J.; Jurss, J. W.; Hoertz, P. G.; Meyer, T. J. 2009. "Catalytic and SurfaceElectrocatalytic Water Oxidation by Redox Mediator-Catalyst Assemblies" Angewandte Chemie International Edition 48 (50): 9473.

(76) Glasson, C. R. K.; Song, W.; Ashford, D. L.; Vannucci, A.; Chen, Z.; Concepcion, J. J.; Holland, P. L.; Meyer, T. J. 2012. "Self-Assembled Bilayers on Indium-Tin Oxide (SAB-ITO) Electrodes: A Design for Chromophore-Catalyst Photoanodes" Inorganic Chemistry 51 (16): 8637.

(77) Song, W.; Ito, A.; Binstead, R. A.; Hanson, K.; Luo, H.; Brennaman, M. K.; Concepcion, J. J.; Meyer, T. J. 2013. "Accumulation of Multiple Oxidative Equivalents at a Single Site by Cross-Surface Electron Transfer on $\mathrm{TiO}_{2}$ " Journal of the American Chemical Society 135 (31): 11587.

(78) Hanson, K.; Torelli, D. A.; Vannucci, A. K.; Brennaman, M. K.; Luo, H.; Alibabaei, L.; Song, W.; Ashford, D. L.; Norris, M. R.; Glasson, C. R.; Concepcion, J. J.; Meyer, T. J. 2012. "Self-Assembled Bilayer Films of Ruthenium(II)/Polypyridyl Complexes Through Layer-byLayer Deposition on Nanostructured Metal Oxides" Angewandte Chemie International Edition $51(51): 12782$. 
(79) Nayak, A.; Knauf, R. R.; Hanson, K.; Alibabaei, L.; Concepcion, J. J.; Ashford, D.; Dempsey, J. L.; Meyer, T. J. 2014. "Synthesis And Photophysical Characterization of Porphyrin and Porphyrin-Ru(II) Polypyridyl Chromophore-Catalyst Assemblies on Mesoporous Metal Oxides" Chemical Science 5: 3115.

(80) Bettis, S. E.; Hanson, K.; Wang, L.; Gish, M. K.; Concepcion, J. J.; Fang, Z.; Meyer, T. J.; Papanikolas, J. M. 2014. "Photophysical Characterization of a Chromophore/Water Oxidation Catalyst Containing a Layer-by-Layer Assembly on Nanocrystalline $\mathrm{TiO}_{2}$ Using Ultrafast Spectroscopy" The Journal of Physical Chemistry A 118 (45): 10301.

(81) Lapides, A. M.; Ashford, D. L.; Hanson, K.; Torelli, D. A.; Templeton, J. L.; Meyer, T. J. 2013. "Stabilization of a Ruthenium(II) Polypyridyl Dye on Nanocrystalline $\mathrm{TiO}_{2}$ by an Electropolymerized Overlayer" Journal of the American Chemical Society 135 (41): 15450.

(82) Ashford, D. L.; Lapides, A. M.; Vannucci, A. K.; Hanson, K.; Torelli, D. A.; Harrison, D. P.; Templeton, J. L.; Meyer, T. J. 2014. "Water Oxidation by an Electropolymerized Catalyst on Derivatized Mesoporous Metal Oxide Electrodes" Journal of the American Chemical Society 136 (18): 6578.

(83) Puodziukynaite, E.; Wang, L.; Schanze, K. S.; Papanikolas, J. M.; Reynolds, J. R. 2014. "Poly(Fluorene-Co-Thiophene)-Based Ionic Transition-Metal Complex Polymers for Solar Energy Harvesting and Storage Applications" Polymer Chemistry 5 (7): 2363.

(84) Wang, L.; Puodziukynaite, E.; Vary, R. P.; Grumstrup, E. M.; Walczak, R. M.; Zolotarskaya, O. Y.; Schanze, K. S.; Reynolds, J. R.; Papanikolas, J. M. 2012. "Competition Between Ultrafast Energy Flow and Electron Transfer in a Ru(II)-Loaded Polyfluorene LightHarvesting Polymer" The Journal of Physical Chemistry Letters 3 (17): 2453.

(85) Ma, D.; Bettis, S. E.; Hanson, K.; Minakova, M.; Alibabaei, L.; Fondrie, W.; Ryan, D. M.; Papoian, G. A.; Meyer, T. J.; Waters, M. L.; Papanikolas, J. M. 2013. "Interfacial Energy Conversion in RuII Polypyridyl-Derivatized Oligoproline Assemblies on $\mathrm{TiO}_{2}$ " Journal of the American Chemical Society 135 (14): 5250.

(86) Wilger, D. J.; Bettis, S. E.; Materese, C. K.; Minakova, M.; Papoian, G. A.; Papanikolas, J. M.; Waters, M. L. 2012. "Tunable Energy Transfer Rates via Control of Primary, Secondary, and Tertiary Structure of a Coiled Coil Peptide Scaffold" Inorganic Chemistry 51 (21): 11324. (87) Ashford, D. L.; Stewart, D. J.; Glasson, C. R.; Binstead, R. A.; Harrison, D. P.; Norris, M. R.; Concepcion, J. J.; Fang, Z.; Templeton, J. L.; Meyer, T. J. 2012. "An Amide-Linked Chromophore-Catalyst Assembly for Water Oxidation" Inorganic Chemistry 51 (12): 6428. (88) Ashford, D. L.; Song, W.; Concepcion, J. J.; Glasson, C. R. K.; Brennaman, M. K.; Norris, M. R.; Fang, Z.; Templeton, J. L.; Meyer, T. J. 2012. "Photoinduced Electron Transfer in a Chromophore-Catalyst Assembly Anchored to $\mathrm{TiO}_{2}$ " Journal of the American Chemical Society 134 (46): 19189.

(89) Norris, M. R.; Concepcion, J. J.; Harrison, D. P.; Binstead, R. A.; Ashford, D. L.; Fang, Z.; Templeton, J. L.; Meyer, T. J. 2013. "Redox Mediator Effect on Water Oxidation in a Ruthenium-Based Chromophore-Catalyst Assembly" Journal of the American Chemical Society 135 (6): 2080.

(90) Wang, L.; Ashford, D. L.; Thompson, D. W.; Meyer, T. J.; Papanikolas, J. M. 2013. "Watching Photoactivation in a $\mathrm{Ru}(\mathrm{II})$ Chromophore-Catalyst Assembly on $\mathrm{TiO}_{2}$ by Ultrafast Spectroscopy" The Journal of Physical Chemistry C 117 (46): 24250.

(91) Norris, M. R.; Concepcion, J. J.; Fang, Z.; Templeton, J. L.; Meyer, T. J. 2013. "LowOverpotential Water Oxidation by a Surface-Bound Ruthenium-Chromophore-RutheniumCatalyst Assembly" Angewandte Chemie International Edition 52 (51): 13580. 
(92) Song, W.; Glasson, C. R. K.; Luo, H.; Hanson, K.; Brennaman, M. K.; Concepcion, J. J.; Meyer, T. J. 2011. "Photoinduced Stepwise Oxidative Activation of a Chromophore-Catalyst Assembly on $\mathrm{TiO}_{2} "$ The Journal of Physical Chemistry Letters 2 (14): 1808.

(93) Abruna, H. D.; Denisevich, P.; Umana, M.; Meyer, T. J.; Murray, R. W. 1981.

"Rectifying Interfaces Using 2-Layer Films of Electrochemically Polymerized Vinylpyridine and Vinylbipyridine Complexes of Ruthenium and Iron on Electrodes" Journal of the American Chemical Society 103 (1): 1.

(94) Abruna, H. D. 1988. "Coordination Chemistry in Two Dimensions: Chemically Modified Electrodes" Coordination Chemistry Reviews 86: 135.

(95) Zhong, Y. W.; Yao, C. J.; Nie, H. J. 2013. "Electropolymerized Films Of Vinyl-

Substituted Polypyridine Complexes: Synthesis, Characterization, And Applications"

Coordination Chemistry Reviews 257 (7-8): 1357.

(96) Sende, J. A. R.; Arana, C. R.; Hernandez, L.; Potts, K. T.; Keshevarzk, M.; Abruna, H. D.

1995. "Electrocatalysis of $\mathrm{CO}_{2}$ Reduction in Aqueous-Media at Electrodes Modified with

Electropolymerized Films of Vinylterpyridine Complexes of Transition-Metals" Inorganic Chemistry 34 (12): 3339.

(97) Moss, J. A.; Yang, J. C.; Stipkala, J. M.; Wen, X. G.; Bignozzi, C. A.; Meyer, G. J.; Meyer, T. J. 2004. "Sensitization And Stabilization Of $\mathrm{TiO}_{2}$ Photoanodes With Electropolymerized Overlayer Films of Ruthenium And Zinc Polypyridyl Complexes: A Stable Aqueous Photoelectrochemical Cell" Inorganic Chemistry 43 (5): 1784.

(98) Ashford, D. L.; Sherman, B. D.; Binstead, R. A.; Templeton, J. L.; Meyer, T. J. 2015. "Electro-assembly of a Chromophore-Catalyst Bilayer for Water Oxidation and Photocatalytic Water Splitting" Angewandte Chemie-International Edition 54 (16): 4778.

(99) Ichinose, K.; Kimikado, Y.; Yoshida, T. 2011. "The Effect of Pre-treatments of F-Doped $\mathrm{SnO}_{2}$ Substrates for Cathodic Nucleation of $\mathrm{ZnO}$ Crystals in Aqueous $\mathrm{ZnCl}_{2}$ Solution with Dissolved $\mathrm{O}_{2}$ " Electrochemistry 79 (3): 146.

(100) Kent, C. A.; Concepcion, J. J.; Dares, C. J.; Torelli, D. A.; Rieth, A. J.; Miller, A. S.; Hoertz, P. G.; Meyer, T. J. 2013. "Water Oxidation and Oxygen Monitoring by Cobalt-Modified Fluorine-Doped Tin Oxide Electrodes" Journal of the American Chemical Society 135 (23): 8432.

(101) Chen, Z. F.; Concepcion, J. J.; Hu, X. Q.; Yang, W. T.; Hoertz, P. G.; Meyer, T. J. 2010. "Concerted O Atom-Proton Transfer in the O-O Bond Forming Step in Water Oxidation" Proceedings of the National Academy of Sciences U S A 107 (16): 7225.

(102) Paracchino, A.; Laporte, V.; Sivula, K.; Grätzel, M.; Thimsen, E. 2011. "Highly Active Oxide Photocathode For Photoelectrochemical Water Reduction" Nature Materials 10: 456.

(103) Poodt, P.; Lankhorst, A.; Roozeboom, F.; Spee, K.; Maas, D.; Vermeer, A. 2010. "A High-Speed Spatial Atomic-Layer Deposition Of Aluminum Oxide Layers For Solar Cell Passivation" Advanced Materials 22: 3564.

(104) Chen, Y. W.; Prange, J. D.; Dühnen, S.; Park, Y.; Gunji, M.; Chidsey, C. E. D.; McIntyre, P. C. 2011. "Atomic Layer Deposited Tunnel Oxide Stabilizes Silicon Photoanodes For Water Oxidation" Nature Materials 10: 539.

(105) Lee, M. H.; Takei, K.; Zhang, J.; Kapadia, R.; Zheng, M.; Chen, Y.-Z.; Nah, J.; Matthews, T. S.; Chueh, Y.-L.; Ager, J. W.; Javey, A.. 2012. "p-Type InP Nanopillar Photocathodes for Efficient Solar-Driven Hydrogen Production" Angewandte Chemie International Edition 51 (43): 10760. 
(106) Song, W.; Brennaman, M. K.; Concepcion, J. J.; Jurss, J. W.; Hoertz, P. G.; Luo, H.; Chen, C.; Hanson, K.; Meyer, T. J. 2011. "Interfacial Electron Transfer Dynamics for $\left[\mathrm{Ru}(\mathrm{bpy})_{2}\left(\left(4,4^{\prime}-\mathrm{PO}_{3} \mathrm{H}_{2}\right)_{2} \text { bpy }\right)\right]^{2+}$ Sensitized $\mathrm{TiO}_{2}$ in a Dye-Sensitized Photoelectrosynthesis Cell: Factors Influencing Efficiency and Dynamics" The Journal of Physical Chemistry C 115 (14): 7081 .

(107) Luo, H. L.; Song, W. J.; Hoertz, P. G.; Hanson, K.; Ghosh, R.; Rangan, S.; Brennaman, M. K.; Concepcion, J. J.; Binstead, R. A.; Bartynski, R. A.; Lopez, R.; Meyer, T. J. 2013. "A Sensitized $\mathrm{Nb}_{2} \mathrm{O}_{5}$ Photoanode for Hydrogen Production in a Dye-Sensitized Photoelectrosynthesis Cell" Chemistry of Materials 25 (2): 122.

(108) Hanson, K.; Losego, M. D.; Kalanyan, B.; Ashford, D. L.; Parsons, G. N.; Meyer, T. J. 2013. "Stabilization of $\left[\mathrm{Ru}(\mathrm{bpy})_{2}\left(4,4^{\prime}-\left(\mathrm{PO}_{3} \mathrm{H}_{2}\right) \mathrm{bpy}\right)\right]^{2+}$ on $\mathrm{Mesoporous} \mathrm{TiO}_{2}$ with Atomic Layer Deposition of $\mathrm{Al}_{2} \mathrm{O}_{3}$ " Chemistry of Materials 25 (1): 3 .

(109) Vannucci, A. K.; Alibabaei, L.; Losego, M. D.; Concepcion, J. J.; Kalanyan, B.; Parsons, G. N.; Meyer, T. J. 2013. "Crossing The Divide Between Homogeneous And Heterogeneous Catalysis In Water Oxidation" Proceedings of the National Academy of Sciences U S A 110 (52): 20918.

(110) Alibabaei, L.; Sherman, B. D.; Norris, M. R.; Brennaman, M. K.; Meyer, T. J. 2015. "Visible Photoelectrochemical Water Splitting into $\mathrm{H}_{2}$ and $\mathrm{O}_{2}$ in a Dye Sensitized

Photoelectrosynthesis Cell" Proceedings of the National Academy of Sciences U S A: ASAP.

(111) Kim, D. H.; Losego, M. D.; Hanson, K.; Alibabaei, L.; Lee, K.; Meyer, T. J.; Parsons, G. N. 2014. "Stabilizing Chromophore Binding On $\mathrm{TiO}_{2}$ for Long-Term Stability of Dye-Sensitized Solar Cells Using Multicomponent Atomic Layer Deposition" Physical Chemistry Chemical Physics 16: 8615.

(112) Chen, Z. F.; Kang, P.; Zhang, M. T.; Meyer, T. J. 2014. "Making Syngas Electrocatalytically Using A Polypyridyl Ruthenium Catalyst" Chemical Communications 50 (3): 335 .

(113) Kang, P.; Chen, Z. F.; Nayak, A.; Zhang, S.; Meyer, T. J. 2014. "Single Catalyst Electrocatalytic Reduction of $\mathrm{CO}_{2}$ in Water to $\mathrm{H}_{2}+\mathrm{CO}$ Syngas Mixtures With Water Oxidation to $\mathrm{O}_{2}$ " Energy \& Environmental Science 7 (12): 4007.

(114) Concepcion, J. J.; Jurss, J. W.; Norris, M. R.; Chen, Z. F.; Templeton, J. L.; Meyer, T. J. 2010. "Catalytic Water Oxidation by Single-Site Ruthenium Catalysts" Inorganic Chemistry 49 (4): 1277.

(115) Chen, Z. F.; Concepcion, J. J.; Meyer, T. J. 2011. "Rapid Catalytic Water Oxidation by a Single Site, Ru Carbene Catalyst" Dalton Transactions 40 (15): 3789.

(116) Wang, M.; Chen, L.; Sun, L. C. 2012. "Recent Progress In Electrochemical Hydrogen Production with Earth-Abundant Metal Complexes as Catalysts" Energy \& Environmental Science 5 (5): 6763.

(117) Powar, S.; Daeneke, T.; Ma, M. T.; Fu, D. C.; Duffy, N. W.; Gotz, G.; Weidelener, M.; Mishra, A.; Bauerle, P.; Spiccia, L.; Bach, U. 2013. "Highly Efficient p-Type Dye-Sensitized Solar Cells Based on Tris(1,2-diaminoethane)Cobalt(II)/(III) Electrolytes" Angewandte ChemieInternational Edition 52 (2): 602.

(118) Tong, L.; Iwase, A.; Nattestad, A.; Bach, U.; Weidelener, M.; Gotz, G.; Mishra, A.; Bauerle, P.; Amal, R.; Wallace, G. G.; Mozer, A. J. 2012. "Sustained Solar Hydrogen Generation Using a Dye-Sensitised NiO Photocathode/BiVO 4 Tandem Photo-Electrochemical Device" Energy \& Environmental Science 5 (11): 9472.

(119) Register, F. “Department of Agriculture: Rural Utilities Service,” 2014. 

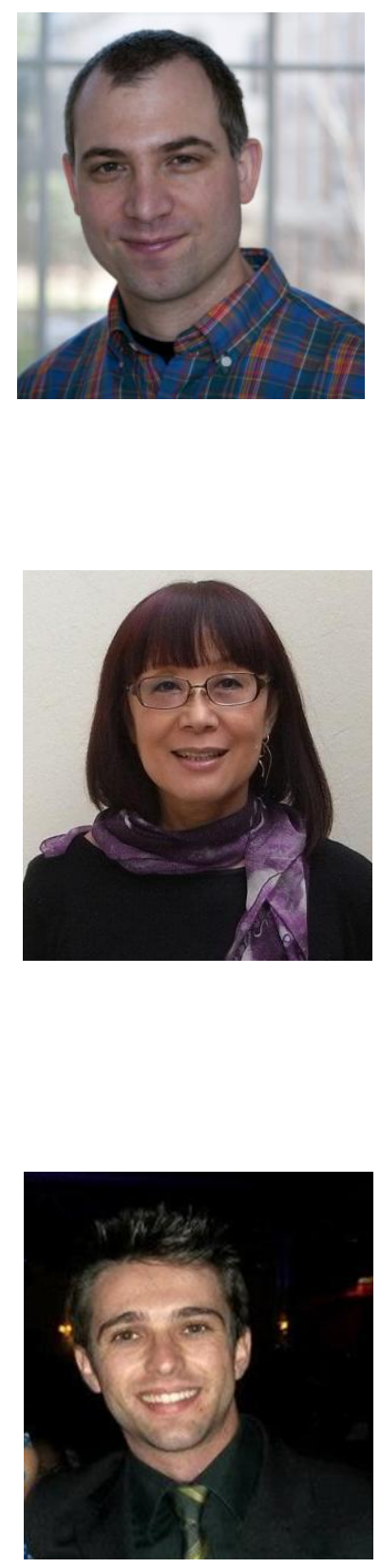

Ralph L. House received his $\mathrm{PhD}$ in Physical Chemistry from the University of North Carolina at Chapel Hill (UNC). He is currently Director of Development and Applied Programs at the University of North Carolina at Chapel Hill Solar Energy Research Center where he specializes in identifying fundamental discoveries that are candidates for applied development and commercialization. Projects are based on research in artificial photosynthesis and solar fuels, with a particular focus in $\mathrm{CO}_{2}$ electrocatalysis.

Neyde Yukie Murakami Iha received her B.S., M.S. and PhD degrees from the Universidade de São Paulo, Brazil, and did postdoctoral work at the Ochanomizu University, Japan, and at the Radiation Laboratory, University of Notre Dame, USA. Coordinator of the Laboratory of Photochemistry and Energy Conversion at the Instituto de Química - USP, her research interests include photochemistry and photophysics of photoresponsive species, photoluminescent sensor, molecular machines and light emitting devices, as well as assemblies for solar energy storage and conversion, extended to Solar Fuels in collaboration with Professor Thomas J. Meyer and his research group at the UNC.

Rodolfo Lopes Coppo received his B.S., 2010, and M.S., 2013, in Chemistry from the Universidade Estadual de Londrina, Brazil. He is a PhD Student at the Universidade de São Paulo since 2014 under the supervision of Professor Neyde Yukie Murakami Iha and will be joining the Meyer group at UNC Chapel Hill in July 2015 for an internship. His research interests include coordination compounds, nanostructured materials and energy conversion devices. 

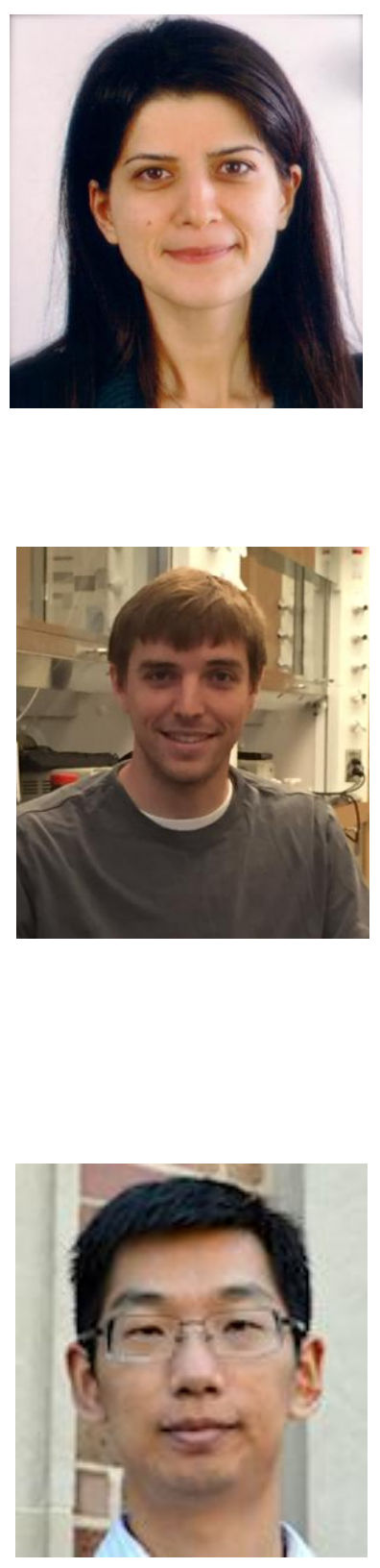

Leila Alibabaei is a Senior Research Scientist at the UNC EFRC. She received her B.S. (1999) and M.S. (2003) from Alzahra University and her Ph.D. (2010) from University of Camerino, Italy. She has been a visiting scholar for 1 year at Laboratory of Photonics and Interfaces, Swiss Federal Institute of Technology in Lausanne, Switzerland. She joined the UNC EFRC in September 2011. Her research interests extend over a broad range of areas including performance characterization of dye sensitized solar cells and the development of nanocrystalline semiconductor films as well as design and fabrication of photoelectrochemical cells.

Benjamin Sherman is a postdoctoral researcher in the lab of Professor Thomas J. Meyer. After finishing a B.S. degree at the University of Michigan, he completed a Ph.D. with Professor Tom Moore at Arizona State University in 2013. His research primarily centers on the integration of molecular dyes and catalysts for the development of a photoelectrochemical systems to carry out the conversion of solar energy to a fuel.

Peng Kang received B.S. in Chemistry from University of Science and Technology of China in 2004 and $\mathrm{PhD}$ in Chemistry from Stanford University in 2010. He was a postdoctoral research associate under joint supervision by Professor Maurice Brookhart and Professor Thomas J. Meyer in the Chemistry Department of UNC-Chapel Hill. His research focuses on reduction of carbon dioxide to fuels and chemicals powered by renewable energy, as was supported by UNC EFRC. He is currently a professor in Technical Institute of Physics and Chemistry of Chinese Academy of Science in China. 

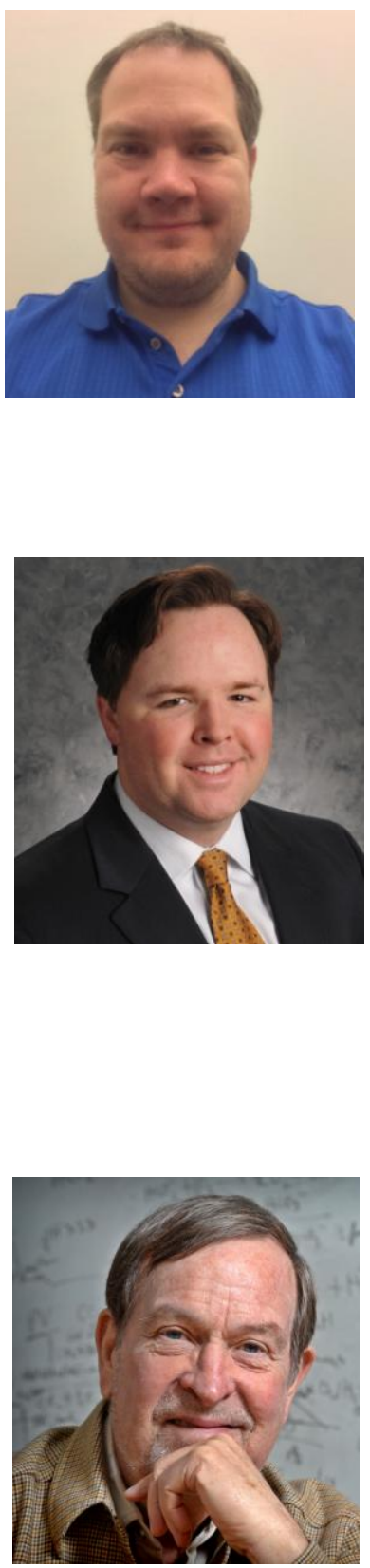

M. Kyle Brennaman received a B.S. from the University of North Alabama in 1998, received his PhD from UNC-Chapel Hill under the direction of Professor John M. Papanikolas in 2004, and completed postdoctoral work at UNC-Chapel Hill under the direction of Professor Thomas J. Meyer from 2005 to 2009. Since then, he has worked in the UNC EFRC as a senior scientist (laser spectroscopist) and facilities director. His research interests include artificial photosynthesis, electron transfer in rigid media, and proton-coupled electron transfer.

Paul G. Hoertz received his B.S. in Chemistry from Fordham University and received his $\mathrm{PhD}$ in Materials Chemistry from Johns Hopkins University. Following postdoctoral research experiences at Pennsylvania State University and UNC Chapel Hill, he served as a Research Chemist at the Research Triangle Institute. He is currently an Applied and Materials Development Scientist at Reynolds American Inc. His research interests include solar energy conversion, energy storage, electron transfer, surface chemistry, nanomaterials, 2D materials, additive manufacturing, and biomaterials.

Thomas J. Meyer designed the first molecular water oxidation catalyst and first described proton coupled electron transfer. He was an early pioneer in the field of artificial photosynthesis and solar fuels. He is a member of the US National Academy of Sciences and the American Academy of Arts and Sciences and has received many awards including the Samson Prize for energy research in 2014. He is currently Arey Professor of Chemistry at UNC Chapel Hill, Director of the UNC Energy Frontier Research Center, and past Vice Chancellor for Graduate Studies and Research at UNC and Associate Laboratory Director at LANL. 